\title{
A Novel Function for Foxm1 in Interkinetic Nuclear Migration in the Developing Telencephalon and Anxiety-Related Behavior
}

\author{
Xiaojing Wu, ${ }^{\star}$ Xiaochun Gu, ${ }^{\star}$ Xiaoning Han, Ailing Du, Yan Jiang, Xiaoyun Zhang, Yanjie Wang, Guangliang Cao, \\ and Chunjie Zhao \\ Key Laboratory of Developmental Genes and Human Diseases, Ministry of Education, Department of Anatomy and Neuroscience, Medical School, \\ Southeast University, Nanjing, 210009, China
}

Interkinetic nuclear migration (INM) is a key feature of cortical neurogenesis. INM functions to maximize the output of the neuroepithelium, and more importantly, balance the self-renewal and differentiation of the progenitors. Although INM has been reported to be highly correlated with the cell cycle, little is known about the effects of cell cycle regulators on INM. In this study, by crossing Foxm $1^{\mathrm{f} / \mathrm{fl}}$ mice with Emx1-Cre line, we report that a conditional disruption of forkhead transcription factor M1 (Foxm1) in dorsal telencephalon results in abnormal cell cycle progression, leading to impaired INM through the downregulation of $C y c l i n b 1$ and $C d c 25 b$. The impairment of INM disturbs the synchronization of apical progenitors (APs) and promotes the transition from APs to basal progenitors (BPs) in a cell-autonomous fashion. Moreover, ablation of Foxm 1 causes anxiety-related behaviors in adulthood. Thus, this study provides evidence of linkages among the cell cycle regulator Foxm1, INM, and adult behavior.

Key words: anxiety-related behavior; cell cycle; Foxm 1; INM; neurogenesis

\section{Introduction}

The neuroepithelium gives rise to a great number of neurons and glial cells during mammalian neocortical development. Both neuroepithelial cells and radial glial cells (RGCs), which form later, are defined as apical progenitors (APs) because these progenitors are localized at the apical surface of the neuroepithelium. APs exhibit a bipolar shape and share an evolutionarily conserved feature: interkinetic nuclear migration (INM). During the cell cycle, the nuclei of the APs move toward the basal side of the ventricular zone (VZ) during $G_{1}$ phase, undergo DNA synthesis ( $S$ phase), migrate rapidly to the apical surface during $G_{2}$ phase, and then undergo mitosis (Götz and Huttner, 2005; Taverna and

Received June 17, 2013; revised Dec. 10, 2013; accepted Dec. 17, 2013.

Author contributions:X.W., X.G., and C.Z. designed research;X.W.,X.G., X.H., A.D., Y.J., X.Z., and Y.W. performed research;G.C. contributed unpublished reagents/analytictools; X.W., X.G., X.H., and C.Z. analyzed data;X.W. and C.Z. wrote the paper.

This work was supported by Grant 91232301 from the National Natural Science Foundation of China (C.Z.), Grant 2012AA022402 from the National High Technology Research and Development Program of China (C.Z. and X.G.), Grant 2013CB733801 from the National Basic Research Program of China (X.G.), Grants 31171040 and 81070904 from the National Natural Science Foundation of China (C.Z.), and Grant 31200823 from the National Natural Science Foundation of China (G.C.). We thank Dr Maureen Gannon (Vanderbilt University Medical Center) and Dr Pradip Raychaudhuri (University of Illinois at Chicago) for providing the Foxm $1{ }^{\mathrm{f} / \mathrm{fl}}$ mice, Dr Ulrich Schüller (Ludwig Maximilian University) for the Foxm1 750 bp fragment plasmid, Yiquan Wei, Li Liu, and Yang Yang for their assistance with laboratory and animal care, and other members of the laboratory for discussion, as well as Dr Xiaojin Yu (School of Public Healthy, Southeast University) for her assistance with the mathematical analysis.

The authors declare no competing financial interests.

*X.W. and X.G. contributed equally to this work.

Correspondence should be addressed to Chunjie Zhao, Southeast University, 87 Dingjiaoqiao Road, Nanjing, Jiangsu, 210009, China. E-mail: zhaocj@seu.edu.cn.

DOI:10.1523/JNEUROSCI.2549-13.2014

Copyright $\odot 2014$ the authors $\quad 0270-6474 / 14 / 341510-13 \$ 15.00 / 0$
Huttner, 2010; Willardsen and Link, 2011). The nuclei of APs at various positions along the apical-basal axis in the VZ give rise to the remarkable pseudostratification of the mammalian neuroepithelium. This feature is thought to maximize the output of the neuroepithelium (Taverna and Huttner, 2010) and to be important for tissue-shape formation (Reiner et al., 2012).

Genetic and pharmacological studies have revealed that the cell cycle is required for INM, although INM is dispensable for normal cell-cycle progression. Furthermore, nuclear migration remains coordinated with the cell cycle when the cell cycle is modified (Murciano et al., 2002; Schenk et al., 2009; Kosodo et al., 2011). Subsequent studies demonstrated that INM is also highly correlated with neurogenesis (Fietz and Huttner, 2011; Willardsen and Link, 2011; Kosodo, 2012). Additionally, INM is important for regulating proliferation versus differentiation (Murciano et al., 2002; Buchman and Tsai, 2008; Kageyama et al., 2009; Latasa et al., 2009; Willardsen and Link, 2011). Forkhead transcription factor M1 (Foxm1), a key cell cycle regulator, is a novel candidate that might link proliferation and differentiation (Yokomine et al., 2010; Kalin et al., 2011). Although the functions of Foxm1 in cell-cycle progression have been well studied (Krupczak-Hollis et al., 2004; Costa, 2005; Laoukili et al., 2007; Schüller et al., 2007; Fu et al., 2008; Radhakrishnan and Gartel, 2008), the link between the cell-cycle regulator Foxm 1 and INM has not yet been examined, and the possible effects of Foxm1 on behavior remain unknown. In the present study, we observed that the conditional disruption of Foxm1 in the telencephalon results in an impairment of INM and abnormal cell-cycle progression; these effects are accompanied by a decrease in the number of APs, which may be due to the downregulation of Cyclin $b 1$ 
and $C d c 25 b$. Furthermore, impaired basal-to-apical INM disturbs AP synchronization, resulting in an increased number of basal progenitors (BPs) in the developing cortex; this leads to a slight reduction in the number of cortical neurons, and the Foxm1 mutants exhibited decreased anxiety-related behavior. Our study demonstrates that the cell-cycle regulator Foxm1 is required for INM, and more importantly, deficiency in Foxm1 has effects on adult behavior.

\section{Materials and Methods}

Generation of mice with dorsal telencephalic-specific

Foxm1 deletion

Foxm $1^{\mathrm{fl} / \mathrm{fl}}$ mice (Kalinichenko et al., 2002) were a kind gift from Dr Maureen Gannon (Vanderbilt University Medical Center) and Dr Pradip Raychaudhuri (University of Illinois at Chicago). Emxl-Cre mice were purchased from The Jackson Laboratory. Exons 4-7 of Foxm 1 are excised upon exposure to Cre recombinase (Gorski et al., 2002), generating the recombinant Foxm 1 allele. A dorsal telencephalon-specific disruption of Foxm1 was accomplished using Emx1-Cre, which drives recombination in both progenitor and projection neurons. Genotyping of the floxed allele was performed by genomic PCR using primer 1 (5' $5^{\prime}$-TAGG AGATACACTGTTATAT- $\left.3^{\prime}\right)$ and primer 2 (5'-TGTGGGAAAATGC TTACAAAAG-3'), which generated a 210 bp floxed band. Because Cremediated recombination also occurred in the olfactory bulb, the Foxm 1 recombined allele was assayed using olfactory bulb DNA with primer 1 and primer 3 ( $5^{\prime}$-CTCATGTAGCATAGAGGGCTG-3'), which generated a 510 bp recombined band (Kalinichenko et al., 2002). Foxm $1^{\mathrm{fl} / \mathrm{fl}}$; Emx1-Cre mice are referred to as Foxm1 cko/mutant mice. The day that a vaginal plug was detected was defined as embryonic day (E) 0.5. All animals were bred in the animal facility at Southeast University. All experiments were performed according to guidelines approved by Southeast University.

In situ hybridization and double labeling with immunohistochemistry

Brains from E10.5 to adult mice were dissected, fixed in 4\% DEPC-PFA overnight, cryoprotected in $30 \%$ sucrose/DEPC-PBS at $4^{\circ} \mathrm{C}$ and embedded in OCT. Coronal sections ( $10 \mu \mathrm{m}$ thick) were obtained using a Leica CM 3050S cryostat and stored at $-70^{\circ} \mathrm{C}$ until use. For Nocht1, Delta-like 1, Hes5, Cyclin b1, and Cdc25b probe preparation, total RNA was extracted from E14.5 brains, and 400-600 bp fragments were subcloned into pBluescript SK vectors and linearized (details available upon request). The Foxm1 probe was a kind gift from Dr Ulrich Schüller (Ludwig Maximilian University; Schüller et al., 2007). In situ hybridization was performed as previously described (Tian et al., 2012). For double labeling with Tbr2 immunostaining, in situ hybridization was performed first; after the color reaction with NBT and BICP, the sections were refixed in $4 \%$ PFA for $30 \mathrm{~min}$, and immunostaining was then performed per standard procedures. Images of in situ hybridization were captured by differential interference contrast microscopy (FV1000; Olympus), and pseudocoloration was performed using the FV10-ASW software (Olympus, v 02.01.02.05).

\section{Immunohistochemistry}

For immunohistochemistry, brains from E12.5 to adult mice were fixed in $4 \%$ PFA, cryoprotected in $30 \%$ sucrose at $4^{\circ} \mathrm{C}$, and sectioned to $10 \mu \mathrm{m}$ using a Leica CM 3050 S cryostat. Sections were washed in PBS, blocked with $10 \%$ normal goat serum, permeabilized in PBS containing $0.1 \%$ Triton X-100 (PBT) for $2 \mathrm{~h}$ and incubated in primary antibody diluted in blocking solution overnight at $4^{\circ} \mathrm{C}$. Sections were subsequently washed in PBT and incubated in secondary antibody for $2 \mathrm{~h}$ at $37^{\circ} \mathrm{C}$. Finally, coverslips were applied. The primary antibodies used for immunostaining were mouse anti-Ki67 (Leica, 1:100), rabbit anti-Ki67 (Abcam, 1:500), rabbit anti-Tuj1 (Covance, 1:1000), rabbit anti-Tbr2 (Abcam, 1:500), rat anti-Ctip2 (Abcam, 1:1000), rabbit anti-Foxp2 (Abcam, 1:1000), rat anti-PH3 (Abcam, 1:1000), mouse anti-PH3 (Cell Signaling Technology, 1:500), rabbit anti-Pax6 (Covance, 1:200), mouse anti-Nestin (DSHB, 1:200), rabbit anti- $\beta$-Catenin (Sigma-Aldrich, $1: 1000$ ), mouse anti-N-Cadherin (Invitrogen, 1:1000), and mouse anti-
Table 1. Primers for quantitative real-time PCR

\begin{tabular}{lll}
\hline & Forward & Reverse \\
\hline FoxM1 & CACTTGGATTGAGGACCACTT & GTCGTTTCTGCTGTGATTCC \\
Delta 1 & CCCTCTGTTCTTATCTCCTTTC & TTCCTCTTCGTCTGGTTTC \\
Notch 1 & GCAACTGTCCTCTGCCATATAC & GTCTTCAGACTCCTTGCATACC \\
Hes 5 & GGTCTCCACGATGATCCTTAAA & GTTCTCCCACATGACCAAGA \\
Ngn2 & CAAACTTTCCCTCTCTGATG & CATTCAACCCTTACAAAAGC \\
Aurora A & CACACGTACCAGGAGACTTACAGA & AGTCTTGAAATGAGGTCCTGGCT \\
Aurora B & GCCCCTGGGGGGACTCTA & GGCATGCACCGACCAGCCAA \\
Cyclin A & TGCACTGGTCTGAGCTCTGTGAAT & TGGAGCCAGAGAAGAACCCAAAGA \\
Cyclin B1 & GGTGTAACGGCCATGTTTATTG & CTGTCTGATCTGGTGCTTAGTG \\
CdC25b & AGTATGAAGGCGGGCATATC & GATTCTCTTGTCCAGGCTACAA \\
GAPDH & AGGTCGGTGTGAACGGATTTG & TGTAGACCATGTAGTTGAGGTCA \\
\hline
\end{tabular}

ZO1 (Invitrogen 1:1000). AlexaFluor 555 donkey anti-mouse IgG (Invitrogen; A31570, 1:500), AlexaFluor 633 goat anti-mouse IgG (Invitrogen; A21050, 1:500), AlexaFluor 488 goat anti-rabbit IgG (Invitrogen, 1:500), AlexaFluor 555 donkey anti-rabbit IgG (Invitrogen, 1:500), and AlexaFluor 488 goat anti-rat IgG (Invitrogen, 1:500) were used as secondary antibodies. DAPI was purchased from Sigma-Aldrich.

\section{BrdU labeling and S- phase calculation}

BrdU (Sigma-Aldrich) and IdU (Sigma-Aldrich) were dissolved in physiological saline at concentrations of 10 and $5 \mathrm{mg} / \mathrm{ml}$, respectively. Nuclei in the early $S$, late $S, G_{2} / M$, and $G_{1}$ phases were labeled by intraperitoneal injection of $\mathrm{BrdU}(50 \mathrm{mg} / \mathrm{kg})$ at $0.5,1.5,5$, or $14 \mathrm{~h}$ before harvest. Antigen retrieval was required for the immunostaining of $\mathrm{BrdU}$ and IdU with the rat anti-BrdU (Abcam, 1:1000) and mouse anti-IdU/BrdU (BD Bioscience, 1:150) primary antibodies. The protocol for S-phase compartment calculation was performed as previously described (Martynoga et al., 2005).

\section{Cumulative BrdU labeling}

Cumulative BrdU labeling in E14.5 embryos was performed by repeated intraperitoneal injections of BrdU into pregnant mice according to the following schedule. The first injection was given between 9:00 A.M. and 10:00 A.M. For the $0-8 \mathrm{~h}$ time points, there was a $2 \mathrm{~h}$ interval between each injection; for the $16 \mathrm{~h}$ time points, there were $4 \mathrm{~h}$ intervals, and for the $24 \mathrm{~h}$ time points, there were $4 \mathrm{~h}$ intervals. The mice were killed $2 \mathrm{~h}(0-8 \mathrm{~h}$ time points) or $4 \mathrm{~h}$ (16 and $24 \mathrm{~h}$ time points) after the last injection (Nowakowski et al., 1989; Calegari et al., 2005). Antigen retrieval was required for the immunostaining of BrdU and IdU with the rat anti-BrdU (Abcam, 1:1000) and mouse anti-IdU/BrdU (BD Bioscience, 1:150) primary antibodies. Nuclei were stained with DAPI.

\section{Measurement of cell-cycle parameters and statistical analyses}

For each time point, the BrdU labeling index was obtained from two independent litters, and three pairs of brains from these two litters were sectioned for immunohistochemistry; at least four nonconsecutive cryosections of the medial cortex were imaged with a confocal microscope (FV1000; Olympus) using a $40 \times$ objective for cell counting. Nuclei in the VZ were identified by DAPI staining, and the cells were counted in a $50-\mu \mathrm{m}$-wide field in each section. Mathematical analysis was performed as previously described (Nowakowski et al., 1989).

\section{Quantitative real-time $P C R$}

Total RNA was isolated from E14.5 dorsal telencephalons using the RNeasy Plus Mini Kit (Qiagen) according to the manufacturer's instructions. Each sample was reverse transcribed using MultiScribe reverse transcriptase (Fermentas). The quantitative PCRs were performed using SYBR Green fluorescent master mix (Roche) on a StepOne Plus RealTime PCR System (Applied Biosystems). Primers were synthesized as shown in Table 1.

\section{Microscopic analysis}

Sections were examined with an Olympus BX61 microscope equipped with the appropriate filter sets and a digital camera (DP71) or with a confocal microscope (FV1000; Olympus). Differential interference con- 

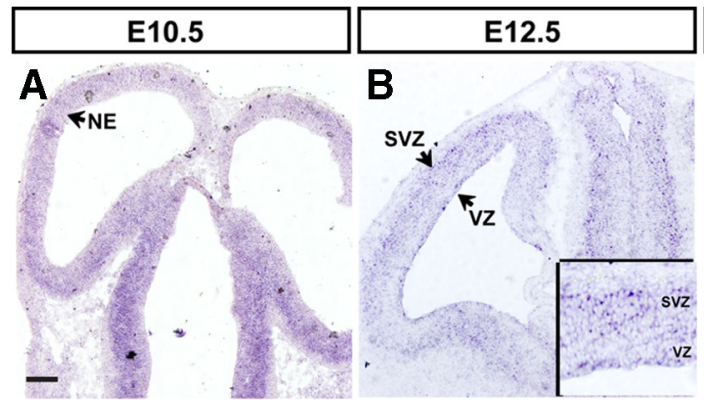

FoxM1 cko E14.5
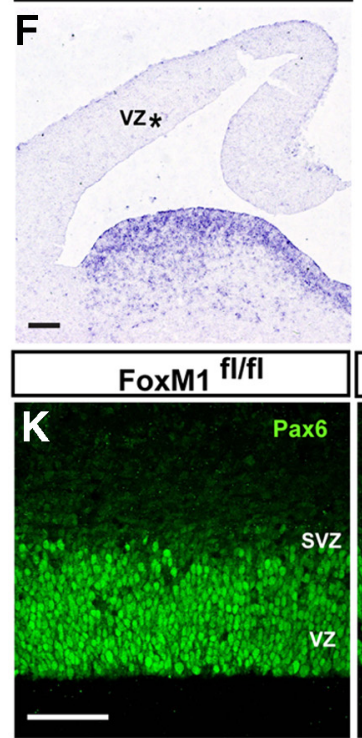

G

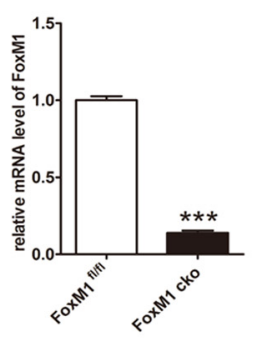

FoxM1 cko

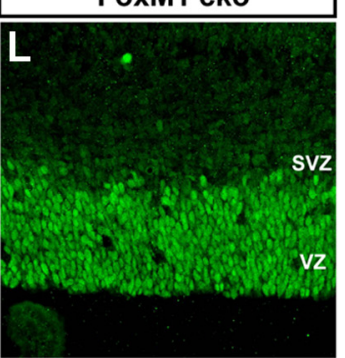

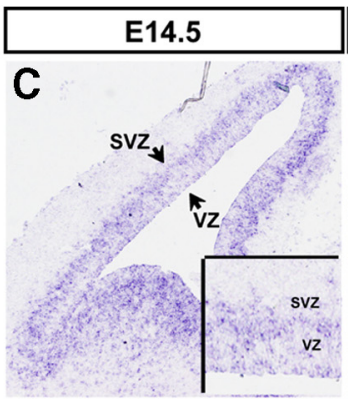
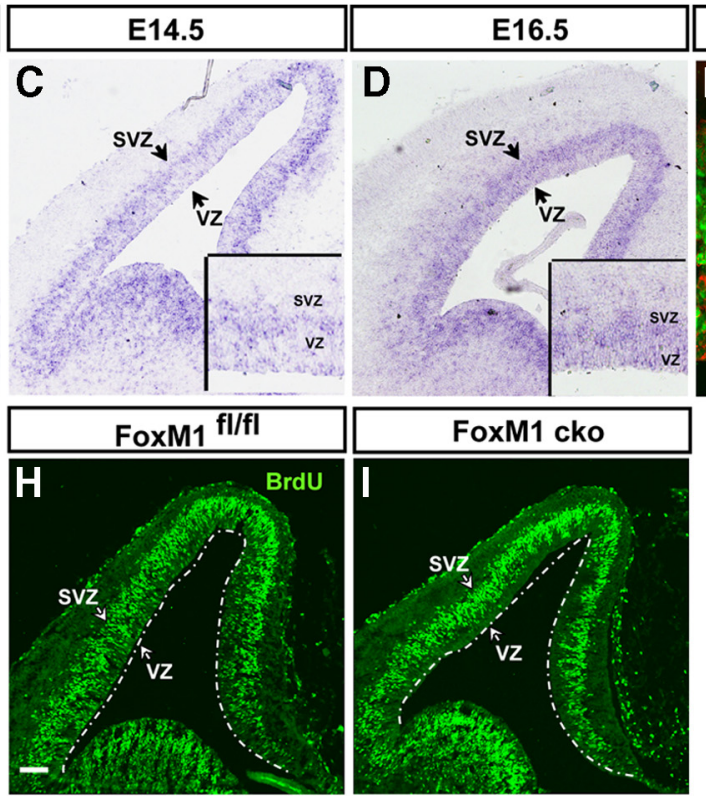

E14.5 Tbr2FoxM1

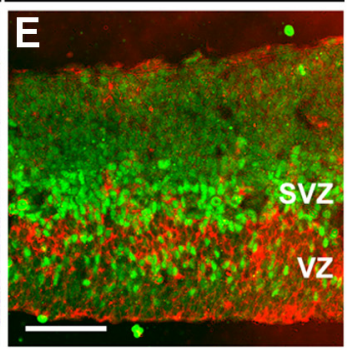

$J$
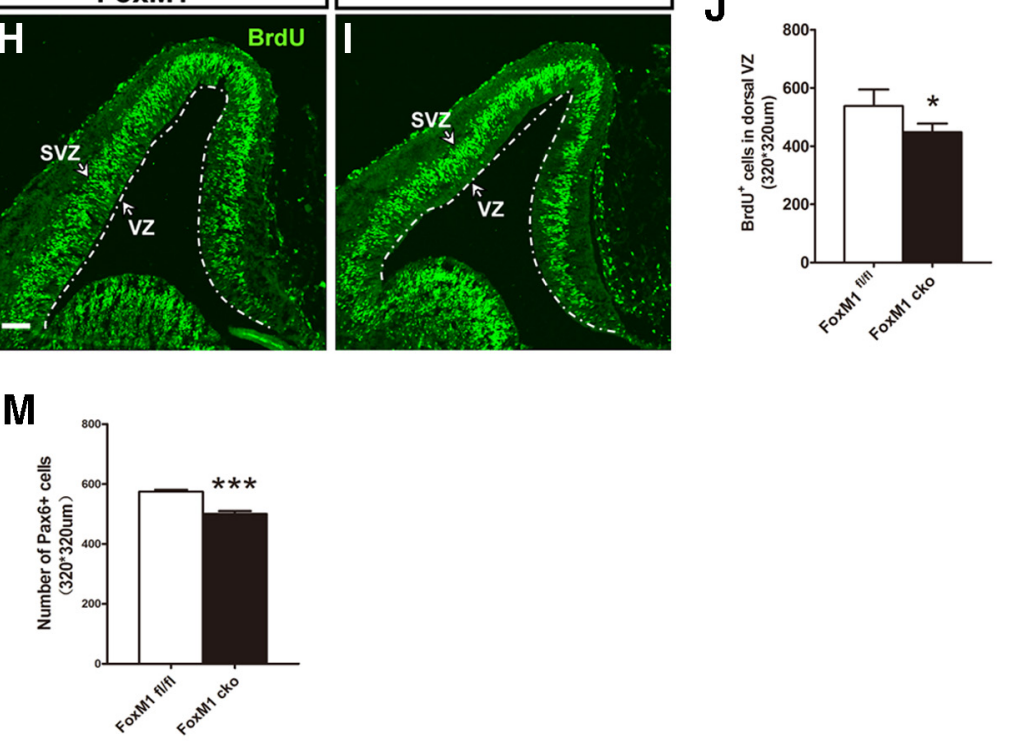

Figure 1. Expression patterns of Foxm 1 during embryonic development and conditional disruption of Foxm 1 in the telencephalon. $A-D$, In situ hybridization of Foxm 1 in coronal sections of E10.5-E16.5 telencephalons. Foxm1 mRNA was detectable at E10.5 $(\boldsymbol{A})$ and covers the entire neuroepithelium (arrow). From E12.5 onward, high levels of Foxm1 mRNA were detected in the overlapping area between the VZ and SVZ ( $\boldsymbol{B}-\boldsymbol{D}$, insets and arrows). $\boldsymbol{E}$, Double staining for Foxm $1 \mathrm{mRNA}$ by in situ hybridization and for Tbr2 by immunostaining. No colocalization of Foxm $1 \mathrm{mRNA}$ and Tbr2 was observed in the basal side of the VZ. $F$, No Foxm $1 \mathrm{mRNA}$ was detected in the Foxm 1 cko dorsal telencephalon (asterisk), whereas normal expression in the basal forebrain was not affected. G, Relative mRNA level of Foxm1. The removal of FoxM1 was demonstrated by quantitative real time-PCR (Foxm $1^{\mathrm{fl} / \mathrm{fl}} \mathrm{N}=5$, Foxm $\left.1 \mathrm{cko} \mathrm{N}=4, p<0.001\right)$. $\boldsymbol{H}-\boldsymbol{J}$, Immunohistochemistry for $1.5 \mathrm{~h}$ BrdU labeling $(\boldsymbol{H}, \boldsymbol{I})$ showed that cell proliferation was decreased. The arrows indicate the range of VZ and SCZ. J, A reduction ( $\sim 16.7 \%)$ in BrdU ${ }^{+}$proliferating cell density was observed

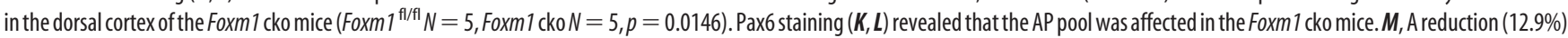
in the Pax6 ${ }^{+}$AP density was observed in the Foxm 1 cko mice $\left(F o x m 1^{f / f f l} N=4, F o x m 1\right.$ cko $\left.N=4, p=0.0005\right)$. The data are presented as the mean \pm SEM. Scale bar, $50 \mu \mathrm{m}$.

trast (DIC) images were obtained from the confocal microscope (FV1000, Olympus) in our laboratory, and we changed the color of the DIC images into red fluorescence using the FV10-ASW software (Olympus, v 02.01.02.05).

\section{Behavioral tests}

Mice were 7 months of age when the tests began. The tests were performed in the following sequence: open-field test, elevated zero maze (O-maze) and fear conditioning.

Open-field test. For the open-field test, each mouse was placed into a square chamber $(40 \times 40 \mathrm{~cm})$. The movement of the mice was recorded using a Unibrain Fire-i digital camera. Data were collected for 15 min. The chamber was cleaned between each trial.

Elevated O-maze. For this test, the equipment was composed of a 6-cm-wide ring with an outer diameter of $45 \mathrm{~cm}$ containing two equal walled (closed) sections and two unwalled (open) sections. The entire ring was elevated to a height of $100 \mathrm{~cm}$. Mice were placed at the boundary of a walled section and an unwalled section, facing the unwalled section. The time spent in the open and closed arms and the total number of entries into the open arm were recorded for $6 \mathrm{~min}$. The open- field test and elevated $\mathrm{O}$-maze results were analyzed using Noldus EthoVision 8.5.

Fear conditioning. Fear conditioning tests were performed following a standard training protocol (Ugo Basile). Mice were placed in a Plexiglas shock chamber and were allowed to explore the chamber for $150 \mathrm{~s}$. A
$2800 \mathrm{~Hz}$ tone was then sounded for $30 \mathrm{~s}$ as the conditioning stimulus; during the last $2 \mathrm{~s}$ of the tone, a $0.8 \mathrm{Ma}$ footshock was delivered. All tests were performed $24 \mathrm{~h}$ after training. For contextual conditioning, mice were placed into the same chamber used for the training test, and freezing times were recorded for $4 \mathrm{~min}$. For cued conditioning, mice were placed into a novel chamber for $3 \mathrm{~min}$; the test lasted $3 \mathrm{~min}$ after the tone used in the training test was played. The freezing time during the pre-tone and post-tone periods was recorded.

\section{Statistical analysis}

Student's $t$ tests were performed to compare region- and layer-specific changes in the developing cortex in absolute and relative percentages of cell numbers. For the BrdU labeling, four pairs of mice were obtained from three different litters; for the cumulative BrdU labeling, three pairs of mice were obtained from two different litters for each time point. In total, 24 pairs of mice from 16 litters were used. For the P8 and adult immunohistochemistry analyses, three pairs of mice were obtained from three different litters; for the in situ hybridization, five control and four FoxM1 cko mice were obtained from three different litters. Three pairs of mice were obtained from three different litters for the real-time PCR analysis. For the embryonic experiments, the gender of the mice was not determined. For the behavior tests, 19 control mice ( 10 males, 9 females) and 14 Foxm 1 mutants ( 7 males, 7 females) were obtained from 12 litters. 

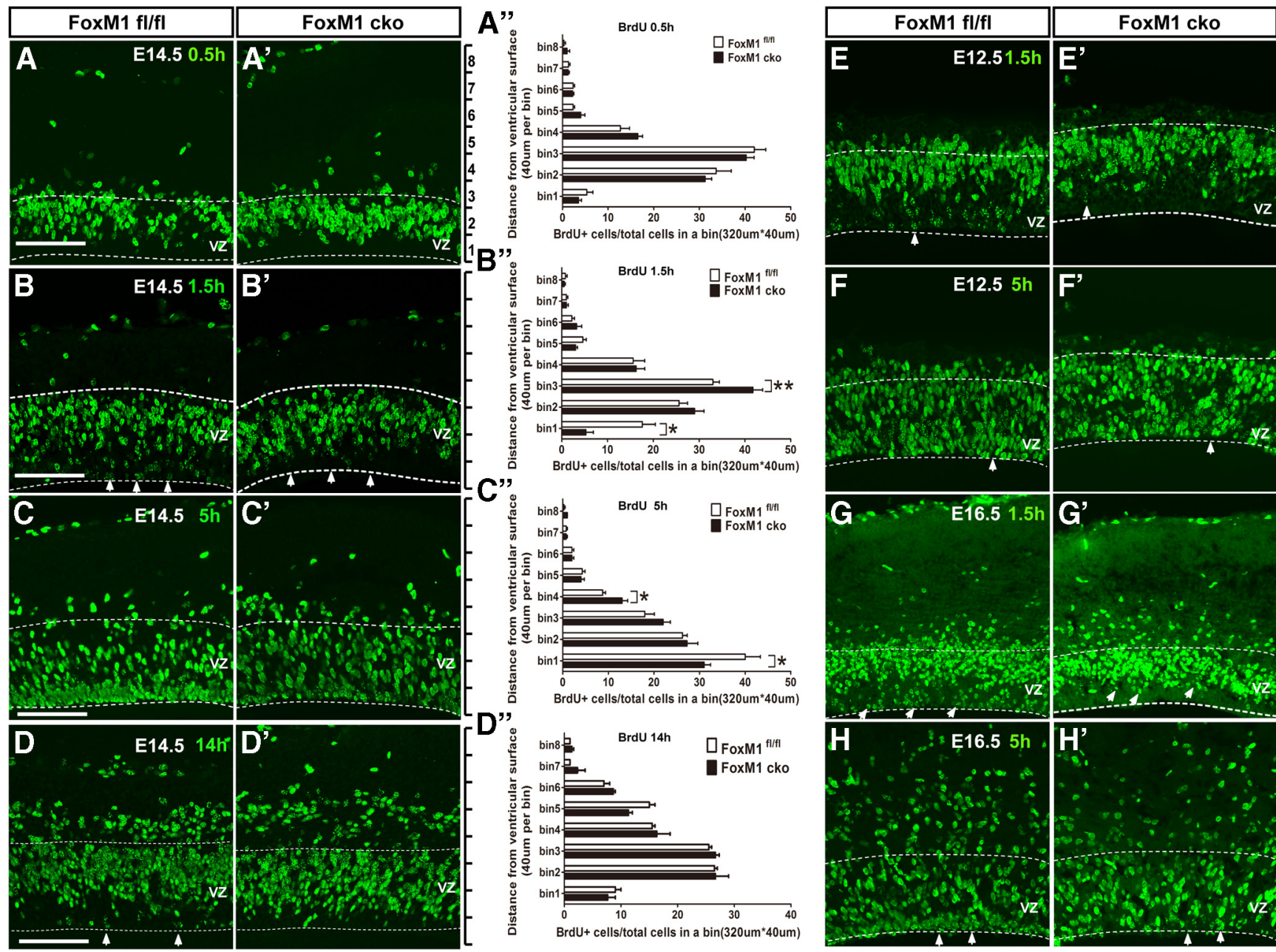

Figure 2. Impairment in the basal-to-apical nuclear migration of neural progenitors. $\boldsymbol{A}-\boldsymbol{D}$, Immunostaining for BrdU in coronal sections of the dorsal telencephalon in E14.5 after $0.5 \mathrm{~h}\left(\boldsymbol{A}, \boldsymbol{A}^{\prime}\right)$, $1.5 \mathrm{~h}\left(\boldsymbol{B}, \boldsymbol{B}^{\prime}\right), 5 \mathrm{~h}\left(\boldsymbol{C}, \boldsymbol{C}^{\prime}\right)$, and $14 \mathrm{~h}\left(\boldsymbol{D}, \boldsymbol{D}^{\prime}\right)$ BrdU injection. The arrows indicate the most apical parts of the ventricular zone. The entire cortex was divided into 8 bins, as indicated, with bin 1 at the VZ and bin 8 at the marginal zone. The percentage of $B r d U^{+}$nuclei in each bin relative to the total number of BrdU ${ }^{+}$cells was measured $\left(\boldsymbol{A}^{\prime \prime}, \boldsymbol{B}^{\prime \prime}, \boldsymbol{C}^{\prime \prime}, \boldsymbol{D}^{\prime \prime} ;\right.$ Foxm $7^{\mathrm{fl} / \mathrm{f}} \mathrm{N}=4, F$ Foxm1 cko $\left.N=4, p<0.001\right)$. $\boldsymbol{E}, \boldsymbol{F}$, Coronal sections through the E12.5 dorsal telencephalon. Immunostaining of nuclei labeled at $1.5 \mathrm{~h}\left(\boldsymbol{E}, \boldsymbol{E}^{\prime}\right)$ and $5 \mathrm{~h}\left(\boldsymbol{F}, \boldsymbol{F}^{\prime}\right)$ after BrdU injections. $\boldsymbol{G}, \boldsymbol{H}$, Coronal sections through the E16.5 dorsal telencephalon. Immunostaining of nuclei labeled at $1.5 \mathrm{~h}\left(\mathbf{G}, \mathbf{G}^{\prime}\right)$ and $5 \mathrm{~h}\left(\boldsymbol{H}, \boldsymbol{H}^{\prime}\right)$ after BrdU injections. Similar abnormal basal-to-apical migration was observed at both E12.5 and E16.5. The arrows in $\boldsymbol{E}-\boldsymbol{H}^{\prime}$ indicate BrdU labeled nuclei that have arrived at the apical surface. The two dashed lines in each figure indicate the apical and basal surfaces of the VZ. The data are presented as the mean \pm SEM. Scale bar, $50 \mu \mathrm{m}$.

Statistical tests were performed with GraphPad 5.0. Differences were considered significant when $p<0.05$.

\section{Results}

The conditional ablation of Foxm 1 in the developing telencephalon results in a decrease in cell proliferation and an abnormal AP pool

To elucidate the function of Foxm 1 in the developing telencephalon, we first examined Foxm1 expression. Foxm 1 mRNA is expressed at high levels throughout the neuroepithelium (E10.5E16.5; Fig. 1A-D). Interestingly, high levels of Foxm 1 expression were detected in the area of overlap between the VZ and subventricular zone (SVZ; Fig. $1 B-D$, insets). We further performed in situ hybridization for Foxm 1 combined with immunostaining for Tbr2, a marker of SVZ BPs, at E14.5. We detected Foxm1 mRNA in APs within the VZ but did not detect colocalization with Tbr2 (Fig. 1E). This expression pattern suggests possible roles for Foxm1 in cell proliferation and differentiation. Next, we conditionally disrupted Foxm 1 in the developing dorsal telencephalon by crossing Foxm $1^{\mathrm{f} / \mathrm{fl}}$ mice with an Emx1-Cre line. As expected, the level of Foxm 1 mRNA was markedly reduced in the dorsal telencephalon (Fig. $1 F, G$ ); the expression of Foxm 1 in the ventral telencephalon was unchanged (Fig. $1 F$ ).

Previous studies have shown that Foxm1 plays an important role in mitotic progression (Wang et al., 2011; Zhang et al., 2011), suggesting that Foxm 1 might be involved in the proliferation of neuronal progenitor cells. To test this hypothesis, we quantified the proliferative capacity of the neuronal progenitors using $1.5 \mathrm{~h}$ BrdU labeling. We detected a decreased number of BrdU-labeled progenitors in Foxm 1 mutants (Fig. $1 H-J$ ). Furthermore, immunostaining for Pax6, a marker of APs in the VZ, was performed on E14.5. Foxm 1 mutants showed a $12.9 \%$ decrease in the number of Pax6 ${ }^{+}$progenitors compared with the control (Fig. $1 K-M$ ). Together, these results suggest that Foxm 1 is required for the proliferation of neuronal progenitors and the maintenance of the AP pool.

\section{Disruption of Foxm1 impairs INM in APs}

Based on the strong Foxm1 expression observed in the VZ and its role in regulating the cell cycle, we suspected that Foxm 1 might play a role in INM. Because the total length of the cell cycle at E14.5 
is $\sim 14-16 \mathrm{~h}$, including a $4 \mathrm{~h} \mathrm{~S}$ phase, $2 \mathrm{~h}$ $\mathrm{G}_{2} / \mathrm{M}$ phase, and $8-10 \mathrm{~h} \mathrm{G}_{1}$ phase, we performed BrdU labeling at time points from 0.5-14 h to track the locations of the nuclei at different phases of the cell cycle. The labeled nuclei of APs that were observed 30 min after BrdU injection were located in the basal zone of the $\mathrm{VZ}$ in both the control and Foxm1 mutants (Fig. $2 A-A^{\prime \prime}$ ), consistent with the known position of AP nuclei during S phase (Latasa et al., 2009). No obvious differences were detected at this point, except that the nuclei of mutant APs appeared to be more condensed than those of control APs. Surprisingly, none of the $1.5 \mathrm{~h}$ labeled nuclei in the mutants reached the apical surface, although a large portion of the labeled nuclei in the control animals did (Fig. $2 B-$ $\left.B^{\prime \prime}\right)$. To more carefully measure nuclear migration, the entire cortex was divided into eight bins, and the number of nuclei in each bin was calculated. We found that in control cortices, $17.6 \pm 2.9 \%$ of the nuclei migrated into bin 1; however, the percentage of basalto-apical migrating nuclei in bin 1 was markedly decreased in the mutant $(5.3 \pm$ $1.7 \%$; Fig. $\left.2 B^{\prime}, B^{\prime \prime}\right)$. Meanwhile, the percentage of BrdU-labeled nuclei remaining in bin 3 was increased in the mutants (41.8 \pm $2.1 \%$ ) compared with the controls (33.0 \pm $1.4 \%$; Fig. $\left.2 B, B^{\prime \prime}\right)$. These results indicate that basal-to-apical nuclear migration is disturbed by the deletion of Foxm1. We then performed $5 \mathrm{~h}$ BrdU labeling. In the control animals, a large proportion $(40 \pm 3.3 \%)$ of BrdU-labeled nuclei had accumulated in bin 1 , the apical zone, and only a small proportion $(8.2 \pm 0.6 \%)$ remained in bin 4 , the basal area of the $\mathrm{VZ}$ (Fig. $2 C, C^{\prime \prime}$ ). In mutant animals, however, the nuclei were dispersed throughout the VZ, with $31 \pm 1.4 \%$ reaching bin 1 and $13 \pm 1.2 \%$ remaining in bin 4 . There was an obvious slowing of basal-toapical nuclear migration (Fig. $2 C^{\prime}, C^{\prime \prime}$ ). Similar defects were also observed for the $1.5 \mathrm{~h}$ and $5 \mathrm{~h}$ BrdU labeling at both E12.5 and E16.5 (Fig. 2E- $H^{\prime}$ ). Moreover, a $14 \mathrm{~h} \mathrm{BrdU}$ labeling was performed to further analyze whether differences in migration exist at later time points in the cell cycle. A similar basal enrichment of BrdU-labeled nuclei was observed in both the controls and mutants, but the control animals displayed a population of BrdU-labeled nuclei at the apical surface, representing the first group of APs that had completed one cell cycle and entered a second $\mathrm{G}_{2}$ phase. In the Foxm1 mutants, all of the BrdU-labeled $\mathrm{G}_{2}$ phase nuclei remained located in the upper area, and none of them had arrived at the apical surface (Fig. $2 D-D^{\prime \prime}$ ). Together, these results indicate that Foxm1 is required for INM, especially basal-to-apical migration. Scale bar, $50 \mu \mathrm{m}$.

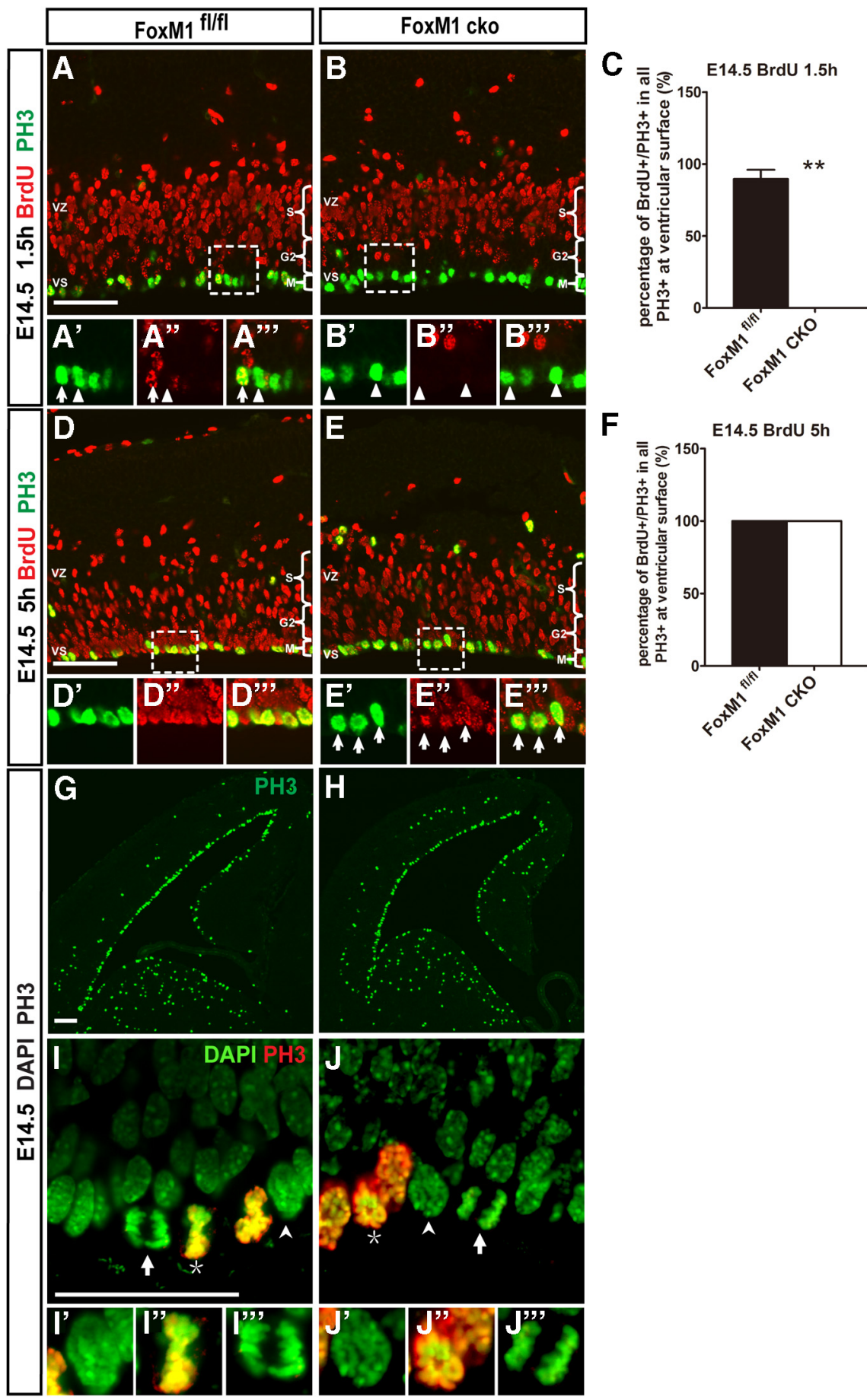

Figure 3. Ablation of Foxm 1 impairs basal-to-apical migration but does not arrest the cell cycle at $M$ phase. $A, B, D, E$, Sections stained for anti-BrdU and PH3 antibodies. $\boldsymbol{A}^{\prime}-\boldsymbol{A}^{\prime \prime \prime}, \boldsymbol{B}^{\prime}-\boldsymbol{B}^{\prime \prime \prime}, \boldsymbol{D}^{\prime}-\boldsymbol{D}^{\prime \prime \prime}$, and $\boldsymbol{E}^{\prime}-\boldsymbol{E}^{\prime \prime}$ are enlarged figures of dashed outlines in $\boldsymbol{A}, \boldsymbol{B}, \boldsymbol{D}$, and $\boldsymbol{E}$, respectively. In the Foxm 1 cko mice, after the $1.5 \mathrm{~h} \mathrm{BrdU}$ labeling, none of the BrdU ${ }^{+}$nuclei reached the apical surface or were colabeled with PH3 $(A, B)$. By $5 \mathrm{~h}$ after BrdU labeling, the BrdU ${ }^{+}$nuclei had arrived at the apical surface and were colabeled with $\mathrm{PH} 3$ in both the wild-type and Foxm 1 cko mice $(\boldsymbol{D}, \boldsymbol{E}) \cdot \boldsymbol{C}, \boldsymbol{F}$, Percentage of $\mathrm{PH} 3^{+}$cells at the ventricular surface that are BrdU ${ }^{+} \mathrm{PH} 3^{+}\left(F_{\text {Foxm }}\right)^{\mathrm{fl} / \mathrm{fl}} \mathrm{N}=3$, Foxm $1 \mathrm{cko} N=$ $3, p=0.017)$. The arrows indicate $\mathrm{BrdU}^{+} \mathrm{PH} 3{ }^{+}$nuclei, the arrowheads indicate $\mathrm{BrdU}{ }^{-} \mathrm{PH} 3{ }^{+}$nuclei. Immunostaining for $\mathrm{PH} 3$ and DAPI $(\mathbf{G}-J)$. The progenitors from both wild-type and Foxm $1 \mathrm{cko}$ mice exhibited normal $M$ phase nuclei. The arrowheads indicate prophase nuclei. Asterisks indicate metaphase nuclei. The arrows indicate anaphase nuclei. The data are presented as the mean \pm SEM.

INM is impaired, but not arrested, and APs are able to pass through M phase in Foxm 1 mutants

Previous studies have shown that a chemical blockade of INM disperses mitotic nuclei from their normal apical locations to 


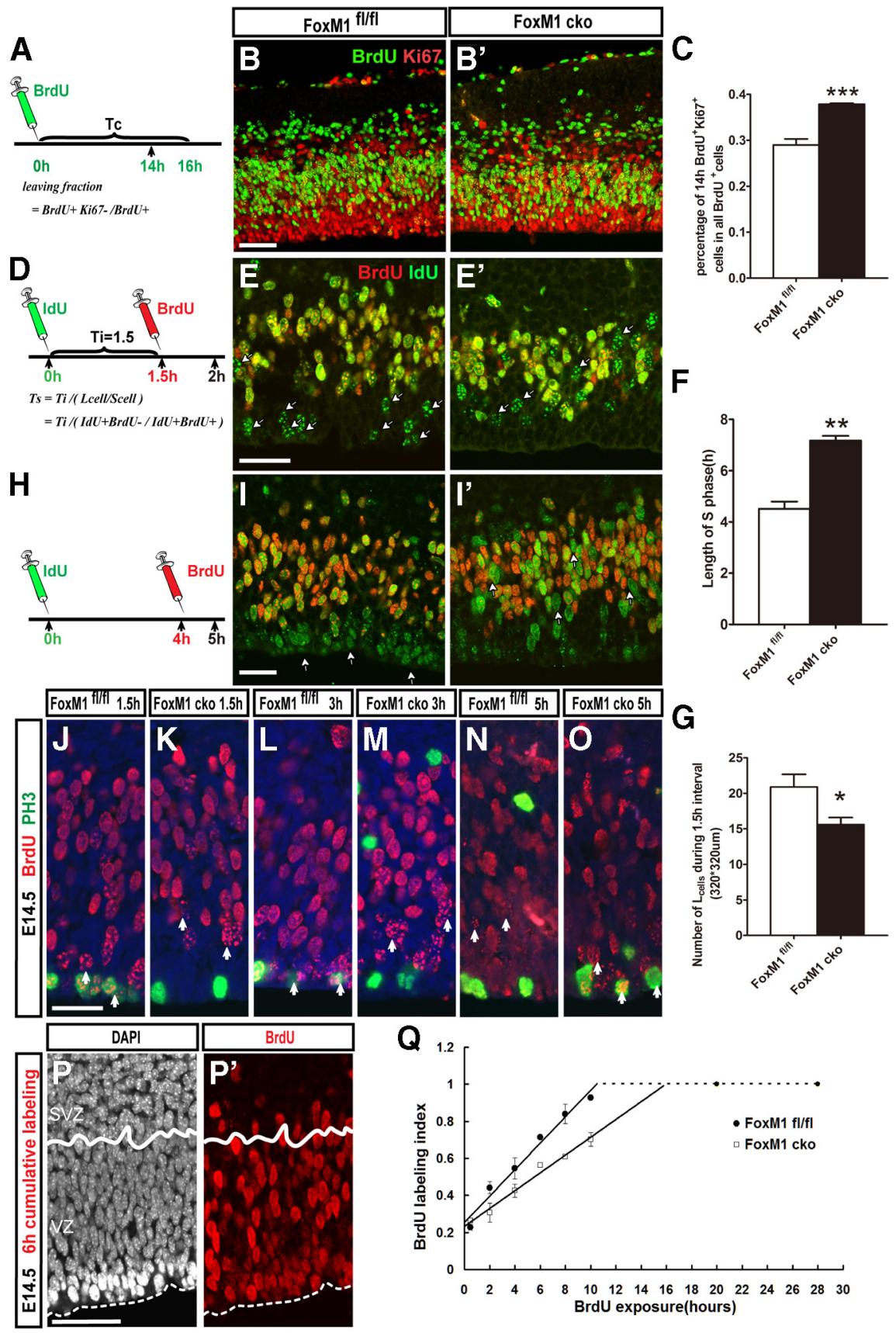

Figure 4. Abnormal cell cycle parameters and disrupted synchronization of APs in the Foxm 1-ablated telencephalon. $\boldsymbol{A}$ $\boldsymbol{D}, \boldsymbol{H}$, Schematic of BrdU and IdU injections. $\boldsymbol{B}, \boldsymbol{E}, \boldsymbol{I}, \boldsymbol{J}-\mathbf{O}$, Coronal sections of $\mathrm{E} 14.5$ telencephalon. $\boldsymbol{B}, \boldsymbol{B} \boldsymbol{B}^{\prime}$, Double staining of anti-BrdU and Ki67 at $14 \mathrm{~h}$ after BrdU injection. C, Percentage of BrdU ${ }^{+}$cells that are BrdU ${ }^{+} \mathrm{Ki}_{67}{ }^{+}$. More BrdU ${ }^{+}$and $\mathrm{Ki}^{+}{ }^{+} \mathrm{APs}$ remained in the cell cycle in the Foxm 1 cko mice than in the wild-type mice (Foxm $1^{\mathrm{fl} / \mathrm{fl}} \mathrm{N}=6$, Foxm 1 cko $\mathrm{N}=$ $5, p=0.0002) . E, E^{\prime}$, Double staining of BrdU and IdU at $2 \mathrm{~h}$ after IdU and $0.5 \mathrm{~h}$ after BrdU injections. The arrows indicate BrdU ${ }^{-} \mathrm{IdU}^{+} \mathrm{G}_{2}$-phase cells. $\boldsymbol{F}$, Foxm 1 cko mice displayed a $\sim 2.7 \mathrm{~h}$ longer $S$ phase than the wild-type mice $\left(\right.$ Foxm $1^{\mathrm{fl} / \mathrm{fl}} \mathrm{N}=$ 3, Foxm 1 cko $N=3, p=0.0014)$. G, Number of BrdU ${ }^{+}$APs that exited S phase within $1.5 \mathrm{~h}$. In the Foxm 1 cko mice, fewer

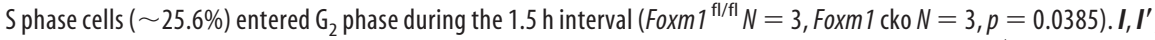
Double staining of BrdU and IdU after the $5 \mathrm{~h} \mathrm{IdU}$ and $1 \mathrm{~h} \mathrm{BrdU}$ injection. The arrows indicate BrdU ${ }^{-}$IdU ${ }^{+} \mathrm{G}_{2}$-phase cells. The INM-mediated synchronization of APs was disturbed. J-O, Double staining of BrdU and PH3 after the $1.5 \mathrm{~h}(\boldsymbol{J}, \boldsymbol{K}), 3 \mathrm{~h}$ $(\boldsymbol{L}, \boldsymbol{M})$ and $5 \mathrm{~h}(\boldsymbol{N}, \mathbf{O})$ injection. The BrdU ${ }^{+}$cells were not colabeled with PH3 until $5 \mathrm{~h}$ after BrdU injection. The data are presented as the mean \pm SEM. The arrows indicate the forefront nuclei. $\boldsymbol{P}, \boldsymbol{P}^{\prime}$, Identification of VZ by DAPI staining. The solid line in $\boldsymbol{P}$ and $\boldsymbol{P}^{\prime}$ indicate the boundary between VZ and SVZ; the dashed line indicate apical surface. $\boldsymbol{Q}$, BrdU labeling index and cumulative BrdU labeling experiments were performed at $0.5 \mathrm{~h}, 2 \mathrm{~h}, 4 \mathrm{~h}, 6 \mathrm{~h}, 8 \mathrm{~h}, 10 \mathrm{~h}, 20$, and $28 \mathrm{~h}$. The regression equations were $y=0.0715 \mathrm{x}+0.2527,2-10 \mathrm{~h} r^{2}=0.974$ (control) and $y=0.048 \mathrm{x}+0.2345,2-10 \mathrm{~h} r^{2}=$ 0.984 (Foxm 1 mutants). The value of $T_{s} T_{C}$ and $T_{C}-T_{s}$ were determined as previously described (Nowakowski et al., 1989). Scale bar, $50 \mu \mathrm{m}$. random sites throughout the VZ during M phase (Murciano et al., 2002; Del Bene et al., 2008). To investigate whether Foxm1 gene deletion would have similar consequences due to its arrest of INM, we performed a time course analysis with double staining for BrdU and phosphohistone $\mathrm{H} 3$ (PH3), an $\mathrm{M}$ phase marker that labels APs undergoing mitosis at the apical surface. After a $1.5 \mathrm{~h} \mathrm{BrdU}$ injection, $\mathrm{PH}^{+}$nuclei were found at the apical surface in both the controls and mutants, and no randomly dispersed mitotic nuclei were observed in the VZ in the mutants, which indicated that INM was not blocked (Fig. 3G,H). In control animals, $\sim 89.7 \pm 3.7 \%$ of $\mathrm{PH}^{+}$nuclei were colabeled with BrdU (Fig. $3 A-A^{\prime \prime \prime}, C$ ), indicating that these progenitors were poised to complete DNA synthesis at the onset of BrdU injection, passed through $G_{2}$ phase and underwent mitosis within $1.5 \mathrm{~h}$. As expected, no PH3 and BrdU double-labeled nuclei were observed in the Foxm 1 mutants, as a result of impaired basal-to-apical nuclear migration (Fig. $3 B-B^{\prime \prime \prime}, C$ ). After a $5 \mathrm{~h}$ BrdU labeling, a smaller subset of BrdUlabeled nuclei reached the apical surface in the mutants, indicating that the basal-toapical migration was slower, but all of the $\mathrm{PH}^{+}$nuclei were found to be colabeled with $\mathrm{BrdU}$ in both the controls and mutants (Fig. $3 D-F$ ).

Previous studies showed that Foxm 1 is required for spindle assembly and centrosome replication (Costa, 2005; Wierstra and Alves, 2007; Xue et al., 2010). Foxm1deficient hepatocytes (Wang et al., 2002) and myocardial cells (Ramakrishna et al., 2007) exhibit enlarged, polyploid nuclei as a result of mitotic arrest. To investigate whether mitotic progression was disrupted, we performed double staining for DAPI and PH3. Identical results were obtained from the controls and Foxm 1 mutants. In prophase, the nuclei exhibited dispersed chromosomes, as shown by DAPI staining. The chromosomes were captured by spindle fibers, aligned at the equatorial plate and colabeled with PH3 during metaphase (Fig. $\left.3 I, J, I^{\prime \prime}, J^{\prime \prime}\right)$, and the chromatids were separated during anaphase (Fig. $\left.3 I^{\prime \prime}, J^{\prime \prime \prime}\right)$. These data show that at least some Foxm1deficient APs are competent to go through $\mathrm{M}$ phase, although there might be problems in $\mathrm{M}$ phase.

Cell-cycle parameters are abnormal, and the synchronization of APs during $S$ and $G_{2}$ phases is disturbed

The normal length of one cell cycle at E14.5 is $\sim 14-16 \mathrm{~h}$. We performed a $14 \mathrm{~h}$ BrdU labeling to investigate whether 
Table 2. Cell cycle parameters of the APs

\begin{tabular}{lcc}
\hline & Control (h) & Foxm1 cko (h) \\
\hline Ts & 3.5 & 4.9 \\
$T \mathrm{C}$ & 14.0 & 20.9 \\
$T \mathrm{c}-T \mathrm{~s}$ & 10.5 & 16 \\
\hline
\end{tabular}

$T c$, Total length of the cell cycle; $T$, length of $S$ phase.

Foxm1 disruption affects the total cell-cycle length. Double immunostaining for BrdU and Ki76, a marker of proliferating cells in all active phases of the cell cycle, showed that the fraction of $\mathrm{BrdU}^{+} \mathrm{Ki}^{+}{ }^{+}$progenitors among all $\mathrm{BrdU}^{+}$cells was $29.0 \pm$ $1.3 \%$ in the control animals but $37.9 \pm 2.1 \%$ in the mutants (Fig. $4 A-C)$, indicating that a greater number of progen-itors remained in the cell cycle (Fig. $4 B-B^{\prime}$ ) and that the cell cycle length might be longer in Foxm 1 mutants than in controls. Because INM is dependent on cell cycle progression, we measured the S-phase duration using IdU and BrdU double labeling to precisely analyze the length of S phase, as previously described (Martynoga et al., 2005). The mice were first treated with IdU to label the progenitors in S phase. After $1.5 \mathrm{~h}$, the mice were treated with BrdU. Thus, the progenitors that remained in S phase would be colabeled by BrdU and IdU, whereas those that had already left $S$ phase and entered $\mathrm{G}_{2}$ would be BrdU ${ }^{-} \mathrm{IdU}^{+}$(Fig. 4D). By calculating the length of $S$ phase (Ts) using the formula $\frac{S_{\text {cell }\left(B r d U^{+} I d U^{+}\right)}}{L_{\text {cell }\left(B r d U^{-} I d U^{+}\right)}}=\frac{T s}{T i_{(1.5 h)}}$, we found that S phase was $\sim 2.7 \mathrm{~h}$ longer in the mutants $(7.2 \pm 0.2 \mathrm{~h})$ than in the control mice $(4.5 \pm$ $0.3 \mathrm{~h}$; Fig. $4 E, F)$. Interestingly, the number of $\mathrm{BrdU}^{-} \mathrm{IdU}^{+} \mathrm{G}_{2}$ phase progenitors in the mutants was lower than that in the controls (Fig. $4 G$ ), which meant that those progenitors without Foxm1 took more time to pass through $S$ phase.

The increased proportion of $\mathrm{BrdU}^{+} / \mathrm{Ki} 7^{+}$, together with the delayed apical-to-basal INM at the $14 \mathrm{~h}$ BrdU injection, raises the possibility that not only $\mathrm{S}$ phase, but also other phases of the cell cycle might also be affected in the Foxm 1 mutants. To precisely measure the cell-cycle parameters, cumulative BrdU labeling was performed (Fig. $4 P, P^{\prime}$ ), and the proportion of $\mathrm{BrdU}^{+}$cells among all VZ cells was counted at $0.5,2,4,6$, $8,10,20$, and $28 \mathrm{~h}$. As expected, the proliferative population in the VZ grew at a steady rate in both the control and Foxm 1 mutant mice; however, the proportion of $\mathrm{BrdU}^{+}$cells in the control was $\sim 10-18 \%$ higher than that of Foxm 1 at each time point until $20 \mathrm{~h}$ (Fig. 4Q). Using linear regression, we were able to acquire a regression curve and calculate the cell-cycle parameters using the regression equation. As shown in Table 2, the length of $S$ phase increased by $38.2 \%$ to $4.9 \mathrm{~h}$ compared with $3.5 \mathrm{~h}$ in the control, whereas the total length of the cell cycle $(T \mathrm{c})$ was $6.8 \mathrm{~h}$ longer in the Foxm 1 mutants $(20.8 \mathrm{~h})$ than in the control $(14 \mathrm{~h})$. Moreover, the value of $T \mathrm{c}-T \mathrm{~s}$, which represents the time that a proliferating, newly BrdU-injected AP takes to pass through $\mathrm{G}_{2}, \mathrm{M}, \mathrm{G}_{1}$, and re-enter $S$ phase, increased from $10.5 \mathrm{~h}$ in the control to $16 \mathrm{~h}$ in the Foxm 1 mutants, which indicated that the lengths of both $\mathrm{G}_{2} / \mathrm{M}$ and $\mathrm{G}_{1}$ phase, as well as $\mathrm{S}$ phase, were prolonged. These results indicate that the entire cell cycle was affected after Foxm 1 ablation. The difference in the $S$ phase lengths determined in the BrdU/IdU double labeling and the cumulative BrdU labeling experiments may result from the different mathematical and statistical methods used; the length of $S$ phase was directly calculated in the BrdU/IdU double-labeling experiments but was indirectly calculated from the regression equation in the cumulative labeling experiments following regression analysis (Nowakowski et al., 1989; Calegari et al., 2005).
Another interesting phenomenon was that, in the control animals, a large portion of the $\mathrm{BrdU}^{-} \mathrm{IdU}^{+} \mathrm{G}_{2}$ phase nuclei had separated from the $\mathrm{BrdU}^{+} \mathrm{IdU}^{+} \mathrm{S}$ phase nuclei and arrived at the apical surface; however, in the Foxm 1 mutants, the BrdU ${ }^{-} \mathrm{IdU}^{+}$ $\mathrm{G}_{2}$ phase nuclei remained in the basal area in a mosaic pattern mixed with $S$ phase nuclei. This result indicates that the synchronization of APs was disturbed (Fig. $4 E-E^{\prime}$ ). To observe this asynchronization more precisely, progenitors were first labeled with IdU for $4 \mathrm{~h}$ and colabeled with BrdU for another $1 \mathrm{~h}$ (Fig. $4 H)$. Consistent with the previous experiments, the control $\mathrm{BrdU}^{+} \mathrm{IdU}^{+} \mathrm{S}$ phase nuclei remained in the basal half of the $\mathrm{VZ}$ after $4 \mathrm{~h}$, whereas most of the BrdU ${ }^{-} \mathrm{IdU}^{+} \mathrm{G}_{2}$ phase nuclei had arrived at the apical surface; thus, nuclei in the $S$ and $G_{2}$ phases were clearly separated. In the Foxm 1 mutants, a similar mosaic distribution of $S$ and $\mathrm{G}_{2}$ phase nuclei was observed (Fig. $4 I-I^{\prime}$ ). Moreover, the first group of IdU-labeled nuclei that entered $\mathrm{G}_{2}$ phase and arrived at the apical surface exhibited a mottled shape; these are referred to as "forefront" nuclei (Fig. 4E,I). In our model, double labeling of $\mathrm{PH} 3$ - and BrdU-labeled forefront nuclei was also observed as early as the $1.5 \mathrm{~h} \mathrm{BrdU}$ labeling (Fig. $4 J$ ), whereas in the Foxm1 mutants, double labeling was not detected until the $5 \mathrm{~h} \mathrm{BrdU}$ labeling (Fig. $4 \mathrm{~K}, \mathrm{M}, \mathrm{O}$ ), indicating an abnormally slow $\mathrm{G}_{2}$ progression. Together, these results suggested that $G_{2}$ phase might also be affected in the Foxm1 mutants, causing the observed defects in AP synchronization during basal-to-apical INM.

\section{Foxm1 is important for maintaining the balance between AP self-renewal and the transition to BPs}

The progenitor cell decision to undergo self-renewal or differentiation is one of the key programs in neurogenesis (Calegari et al., 2005; Dehay and Kennedy, 2007; Fietz and Huttner, 2011), and both INM and the cell cycle are involved in this process. During cortical neurogenesis, APs generate BPs, also called intermediate progenitors (Götz and Huttner, 2005), through asymmetric cell division (Zhong and Chia, 2008; Shitamukai and Matsuzaki, 2012). Our results have shown that Foxm1 regulates the cell cycle, INM, and AP synchronization. Therefore, we investigated whether the impairments in the cell cycle and INM affect the BPs. As shown by immunostaining for Tbr2, the deletion of Foxm1 resulted in an increase in the total number of BPs in the entire cortex (Fig. $5 A-C$ ), and the number of BPs in the VZ also increased (Fig. 5D-F). Tbr $2^{+}$BPs are normally generated through either BP self-renewal within the SVZ or the transition from APs in the VZ. Double immunostaining with BrdU ( $14 \mathrm{~h}$ injection) and Tbr2 showed that the percentage of Tbr $2^{+} \mathrm{BrdU}^{+} \mathrm{APs}$ in the VZ, which corresponded to the APs that were poised to leave $G_{1}$ phase and differentiate into BPs, was significantly increased in the mutants (Fig. $5 G-K$ ), indicating that the transition from APs to BPs was enhanced in the VZ. Interestingly, we also observed a twofold increase in the number of nonsurface mitotic $\mathrm{PH} 3^{+}$proliferating cells in the SVZ of the mutants (Fig. $5 \mathrm{~N}$ ). As expected, the number of Tbr $2^{+} \mathrm{PH} 3{ }^{+}$nonsurface mitotic BPs showed similar increase in Foxm1 cko (Fig. 5O). The increased number of Tbr2 ${ }^{+} \mathrm{PH}^{+}{ }^{+}$cells may indicate that the BPs in the SVZ that were generated from Foxm1-deficient APs also exhibited a similarly slow cell cycle progression, and the prolonged cell cycle allowed more BPs to remain in the cell cycle before they migrated away from the SVZ (Fig. $5 L, M$ ). Our results indicate that Foxm1 is important for maintaining the balance between AP self-renewal and the transition to BPs; the disruption of Foxm1 promotes embryonic neurogenesis by generating more BPs. 


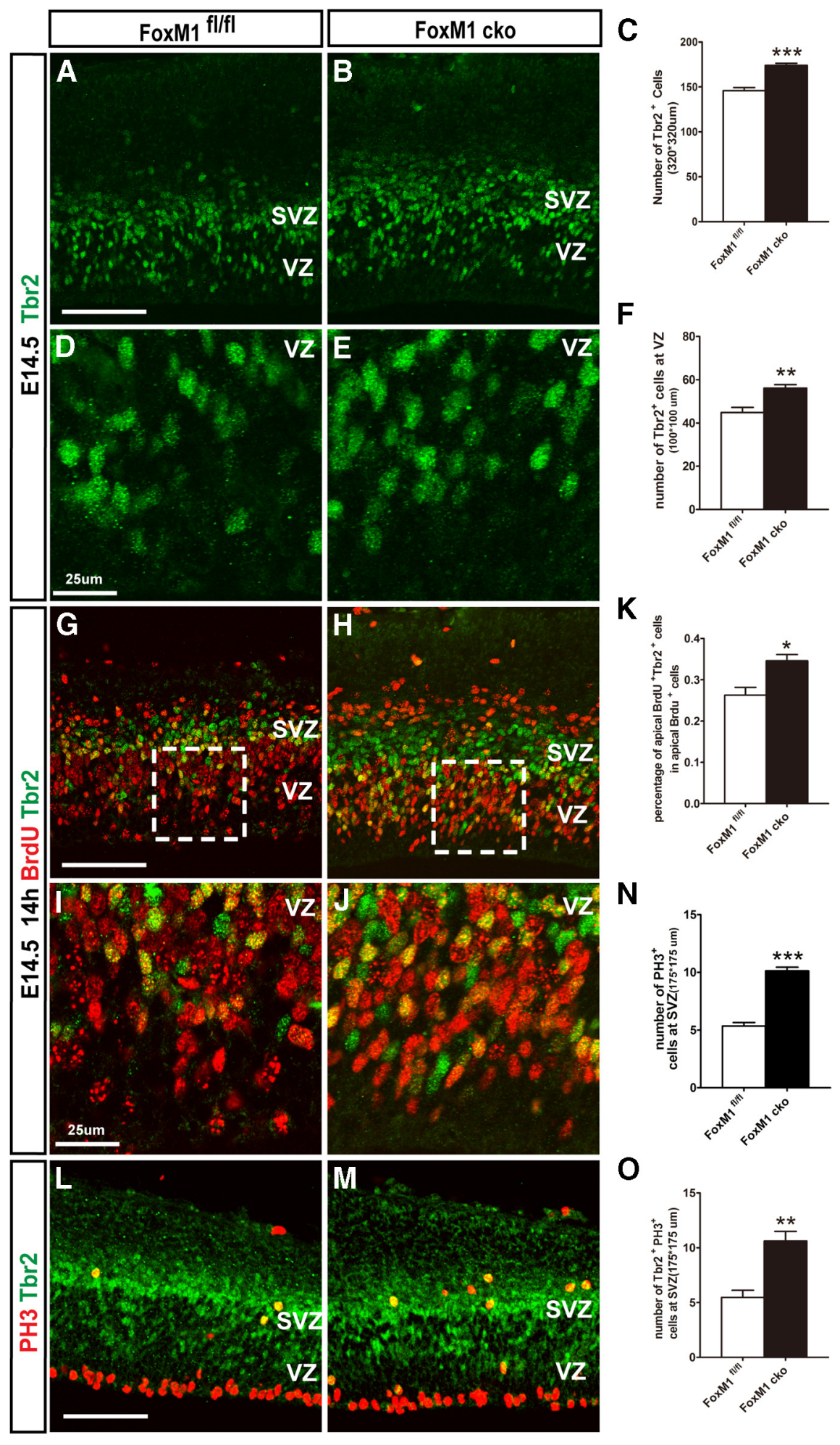

Figure 5. Increased transition from APs to BPs. $\boldsymbol{A}, \boldsymbol{B}, \boldsymbol{D}, \boldsymbol{E}$, Immunostaining for anti-Tbr2. The Foxm 1 cko mice exhibited a larger number of Tbr2 ${ }^{+}$cells in both the SVZ $(\boldsymbol{A}, \boldsymbol{B})$ and VZ $(\boldsymbol{D}, \boldsymbol{E})$. C . The total of Tbr2 ${ }^{+}$cells was increased by $\sim 19.3 \%$ in the Foxm $1 \mathrm{cko}$ mice compared with the wild-type mice (Foxm $1^{\mathrm{fl} / \mathrm{fl}} \mathrm{N}=6$, Foxm1 cko $\left.N=5, p=0.0001\right)$. $\boldsymbol{F}$, The density of the Tbr2 ${ }^{+}$cells in the VZ was increased $25.2 \%$ in the Foxm 1 cko mice compared with the wild-type mice (Foxm $1^{\mathrm{fl} / \mathrm{fl}} \mathrm{N}=5$, Foxm 1 cko $\mathrm{N}=5, p=$ 0.0048). $\mathbf{G}-\boldsymbol{J}$, Double staining for BrdU and Tbr2. I and $\boldsymbol{J}$ are enlarged figure of dashed outlines in $\boldsymbol{G}$ and $\boldsymbol{H}$, respectively. There were more APs transitioning into BPs in the Foxm 1 cko mice. $\boldsymbol{K}$, The density of the BrdU ${ }^{+} \mathrm{Tbr}{ }^{+}$cells in the VZ of the Foxm 1 cko mice was $\sim 31.8 \%$ greater than in the wild-type mice $\left(F o x m 1^{\mathrm{fl} / \mathrm{fl}} \mathrm{N}=3\right.$, Foxm $\left.1 \mathrm{cko} N=3, p=0.0259\right)$. L, M, Double staining for Tbr2 and PH3. $\mathbf{N}$, The density of the PH3 ${ }^{+}$cells in the SVZ (Foxm $1^{\mathrm{fl} / \mathrm{fl}} N=7$, Foxm1 cko $\left.N=7, p<0.0001\right)$. 0 , The density of the $\mathrm{Tbr}^{+}{ }^{+} \mathrm{PH} 3{ }^{+}$cells in the SVZ (Foxm ${ }^{\mathrm{fl} / \mathrm{fl}} \mathrm{N}=5$, Foxm $\left.1 \mathrm{cko} N=4, p=0.0092\right)$. The density of both the PH3 ${ }^{+}$and Tbr2 ${ }^{+} \mathrm{PH} 3{ }^{+}$ proliferating BPs in the SVZ was increased by $\sim 2$-fold in the Foxm 1 cko mice compared with the wild-type mice. The data are presented as the mean \pm SEM. Scale bars: $\boldsymbol{A}, \boldsymbol{B}, \boldsymbol{G}, \boldsymbol{H}, \boldsymbol{L}, \boldsymbol{M}, 50 \mu \mathrm{m} ; \boldsymbol{D}, \boldsymbol{E}, \mathbf{I}, \mathbf{J}, 25 \mu \mathrm{m}$.
The $\mathrm{G}_{2}$ phase regulators Cyclin $b 1$ and $C d c 25 b$ are downregulated in the Foxm1 cko dorsal telencephalon To identify possible molecular mechanisms in Foxm 1 regulation of INM and the defects in cell cycle progression, we analyzed the mRNA levels of cell cycle regulators important for different cell-cycle phases, such as the $S$ phase regulators $C y$ clin $a$ and $C d k 2, \mathrm{G}_{2} / \mathrm{M}$ phase regulators Cyclin $b 1$ and $C d c 25 b$, and $\mathrm{G}_{1}$ phase regulators Cyclin $d 1$ and Aurora $a$ and $b$ (Laoukili et al., 2007, 2008; Wierstra and Alves, 2007; Kalin et al., 2011). Interestingly, there was a 70\% downregulation of the mRNA level of the $\mathrm{G}_{2} / \mathrm{M}$-phase regulator Cyclin b1 (Fig. 6A). Moreover, another important regulator, $C d c 25 b$, which usually binds to Cyclin b1, was similarly reduced in the mutants (Fig. 6A). This finding was further confirmed by in situ hybridization. In control animals, both Cyclin $b 1$ and $C d c 25 b$ showed a specific apical-high/basal-low expression pattern in the VZ, consistent with the fact that the expression of these two factors begins at $S$ phase, reaching their maximum levels in $\mathrm{G}_{2} / \mathrm{M}$ phase and function in $\mathrm{G}_{2} / \mathrm{M}$ phase (Fig. $6 C-F$ ). In the mutants, very weak signals were detected only at the basal germinal zone, with a loss of high expression levels at the apical surface (Fig. $6 C^{\prime}, D^{\prime}, E^{\prime}$, $F^{\prime}$ ). Our data suggest that Foxm1, together with its downstream factors Cyclin $b 1$ and $C d c 25 b$, is required for normal cell-cycle progression. Loss of Foxm1 downregulated the expression of Cyclin $b 1$ and $C d c 25 b$ in apical half of $\mathrm{VZ}$ and might be why basal-to-apical INM and the length of the cell cycle were disturbed in the Foxm1 mutants.

Notch-Delta signaling is not affected in the Foxm 1 mutants

Previous studies have shown that cell fate determination in the neuroepithelium is controlled by lateral inhibition through the selective activation of Notch-Delta signaling. AP synchronization is favored by lateral inhibition, and groups of APs are synchronized at specific mitotic stages through INM (Murciano et al., 2002; Buchman and Tsai, 2008; Kageyama et al., 2009; Latasa et al., 2009; Willardsen and Link, 2011). We observed that both Notch1 and Delta-like 1 were expressed in normal apical-high and basal-low gradients in the control and Foxm1 cko mice. Moreover, no differences in the expression levels of their downstream targets Ngn2 and Hes5 were detected (Fig. 6B, $\left.G-J^{\prime}\right)$. These results indicate that the increased transition from APs to BPs in the 
A

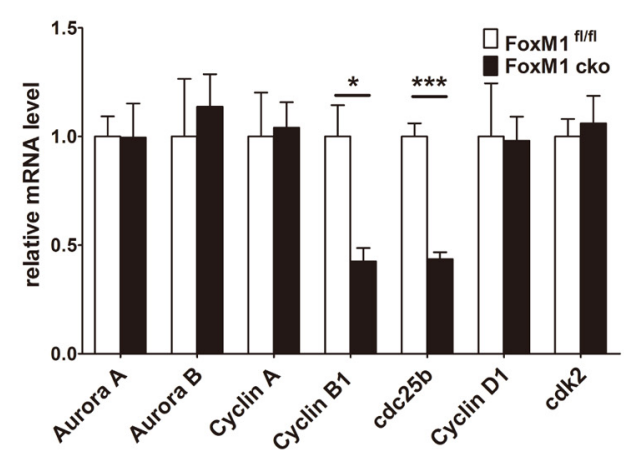

B

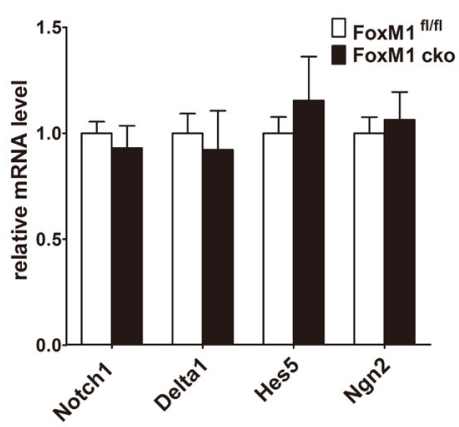

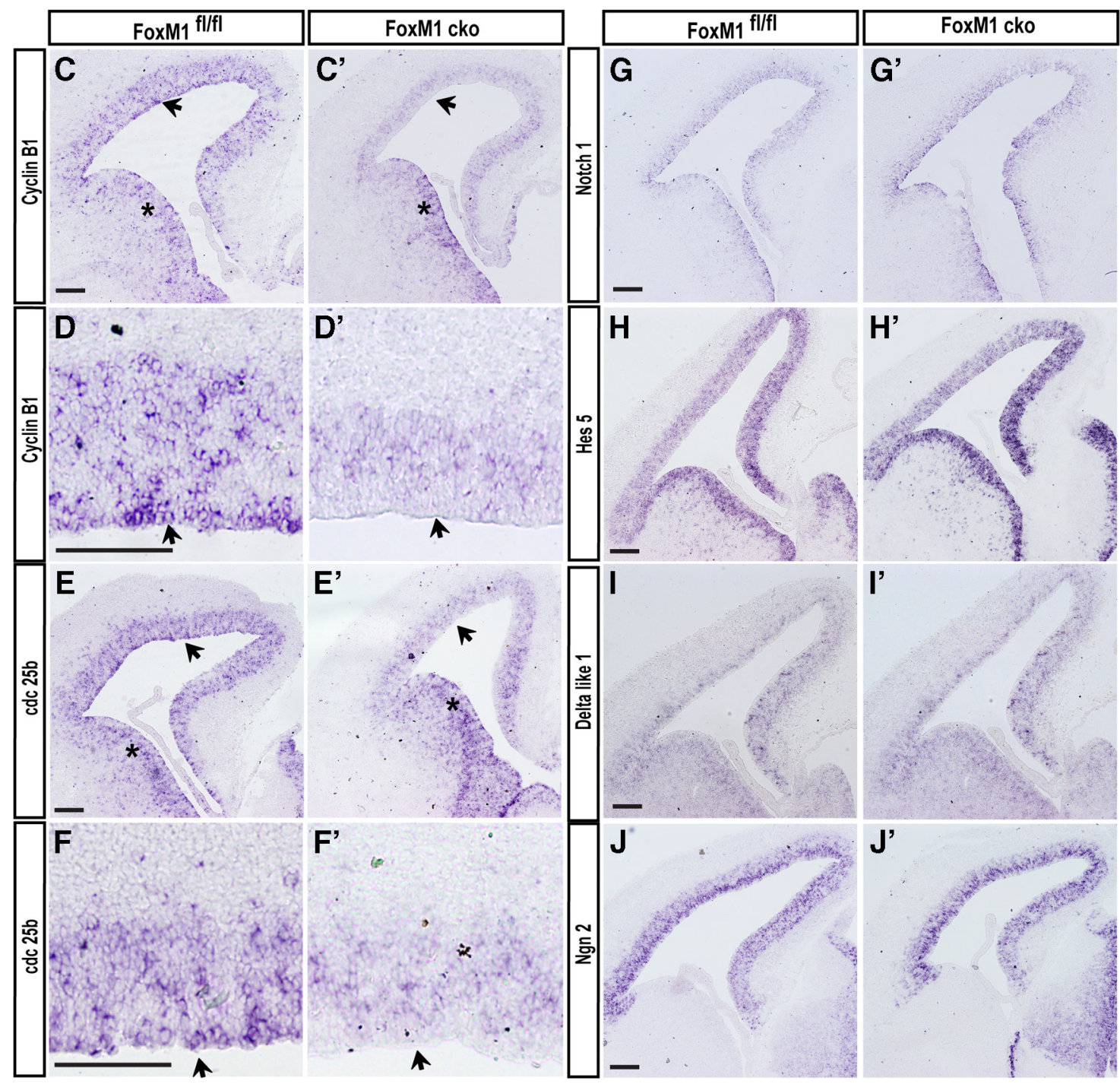

Figure 6. Downregulation of $\mathrm{G}_{2} / \mathrm{M}$ regulators in the dorsal telencephalon. $A$, Relative $m R N A$ levels of cell cycle regulators were determined using quantitative real time-PCR. The $m R N A$ levels of the $\mathrm{G}_{2} / \mathrm{M}$ phase regulators Cyclin $b 1$ and $\left(d \mathrm{c} 25 \mathrm{~b}\right.$ mRNA were reduced in the Foxm 1 cko mice $\left(F o x m 1^{\mathrm{fl} / \mathrm{fl}} \mathrm{N}=3\right.$, Foxm $1 \mathrm{cko} N=3$; Cyclin b1, $p<0.05 ;$; d c25b, $\left.p<0.001\right)$, whereas other cell cycle regulators were not affected. $\boldsymbol{B}$, The relative mRNA levels of Notch1 and its direct targets were measured using quantitative real time-PCR (Foxm $1^{\mathrm{fl} / \mathrm{fl}} \mathrm{N}=3$, Foxm $\left.1 \mathrm{cko} \mathrm{N}=3\right)$; a similar level of

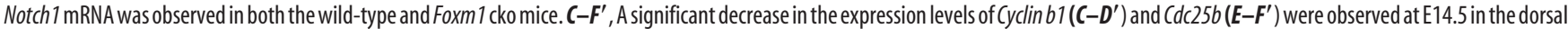
(arrow) but not basal forebrain (asterisk). $\mathbf{G}-\boldsymbol{J}^{\prime}$, Normal expression of $\operatorname{Notch} 1\left(\mathbf{G}, \mathbf{G}^{\prime}\right)$, Hes5 $\left(\boldsymbol{H}, \boldsymbol{H}^{\prime}\right)$, Delta-like $1\left(\boldsymbol{I}, \boldsymbol{I}^{\prime}\right)$, and $\operatorname{Ngn} 2\left(\boldsymbol{J}, \boldsymbol{J}^{\prime}\right)$. The data are presented as the mean \pm SEM. Scale bar, $50 \mu \mathrm{m}$.

Foxm1 mutants does not involve Notch signaling and that Foxm1 acts cell-autonomously in INM and fate determination.

\section{Disruption of Foxm1 results in decreased anxiety-related behavior in adults}

Our results suggest a predominantly early embryonic role for Foxm1 in INM, the cell cycle and the AP to BP transition. To investigate whether abnormal early development affects adult cortical morphology, we performed immunostaining for NeuN, a transcription factor expressed in mature neurons. We found a slight but significant (13.3\%) decrease in the number of $\mathrm{NeuN}^{+}$ neurons in mutant cortices (Fig. 7A-C); a similar defect was observed by Nissl staining (data not shown). Immunostaining for distinct cortical layer-specific markers (CDP, Satb2, Ctip2, and 


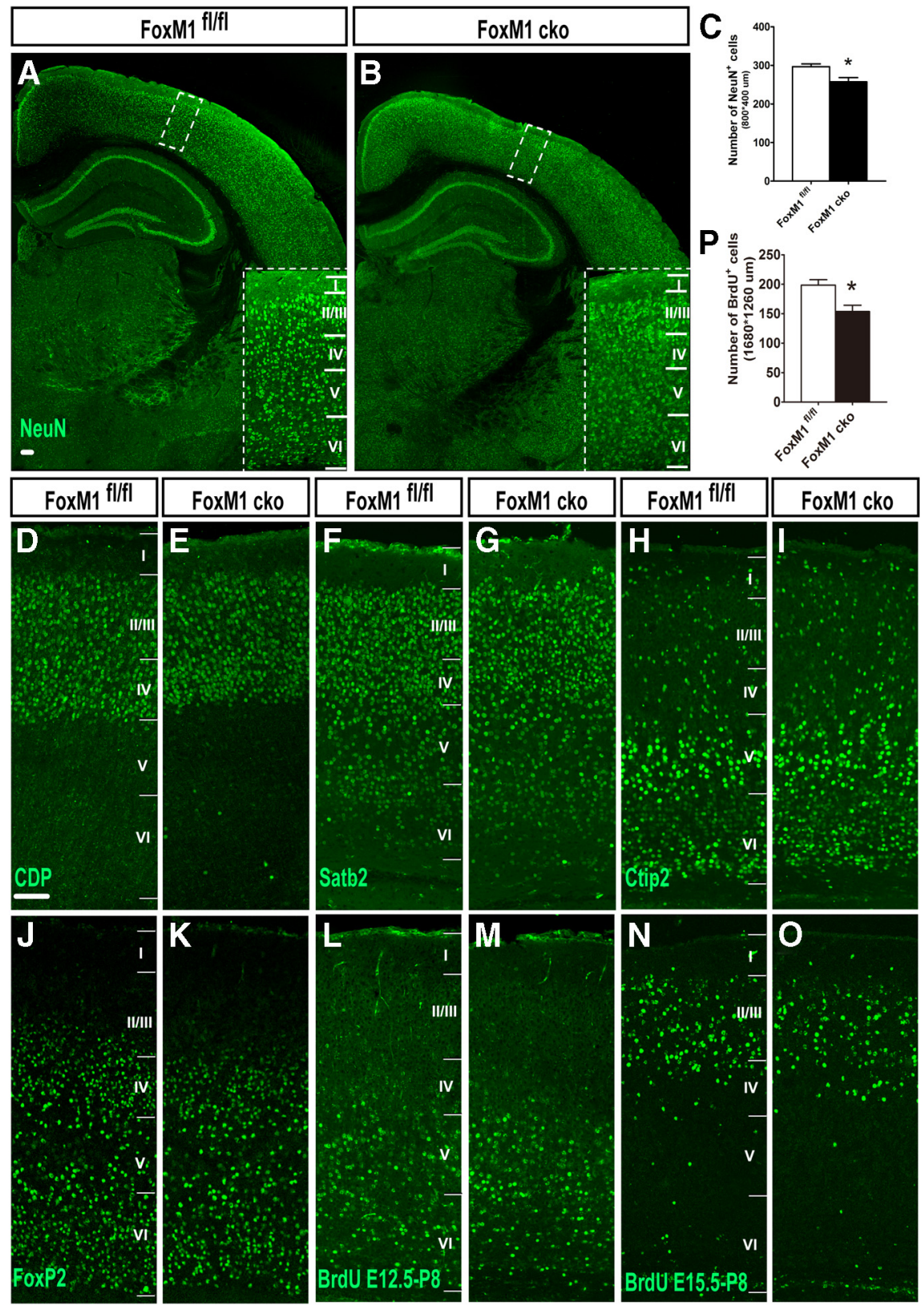

Figure 7. Decreased numbers of neurons in the Foxm 1 mutant adult cortex. $A, B$, Coronal sections of the adult motor-sensory cortex. Immunostaining for NeuN ( $\boldsymbol{A}, \boldsymbol{B}$ and insets). $\boldsymbol{C}$, The number of $\mathrm{NeuN}^{+}$neurons in an $800 \times 400 \mu \mathrm{m}$ region of the adult sensory cortex. The Foxm 1 cko mice exhibited a $\sim 13 \%$ decrease in NeuN ${ }^{+}$neurons compared with the controls $\left(\right.$Foxm ${ }^{1 / / f 1} \mathrm{~N}=$ 3, Foxm 1 cko $N=3, p=0.0397)$. D- $\mathbf{0}$, Coronal sections of the P8 sensory cortex. Immunostaining for the following layer-specific transcription factors was performed: CDP (layers II/III and IV; $\boldsymbol{D}, \boldsymbol{E}$ ), Satb2 (layers II-V; $\boldsymbol{F}, \boldsymbol{G}$ ), Ctip2 (layers V-VI; $\boldsymbol{H}, \boldsymbol{I}$ ) and FoxP2 (layers IV-VI; $\boldsymbol{J}, \boldsymbol{K})$. The neurons generated at E12.5 and E15.5 were labeled with BrdU and observed at P8 (E12.5, $\boldsymbol{L}, \boldsymbol{M} ; \mathrm{E} 15.5, \boldsymbol{N}$, O). $\boldsymbol{P}$, Number of E15.5-labeled BrdU ${ }^{+}$neurons in a $1680 \times 1260 \mu \mathrm{m}$ area of the sensory cortex. The Foxm 1 cko tissue showed a $\sim 22.6 \%$ decrease in the number of BrdU ${ }^{+}$neurons compared with the controls $\left(F o x m 7^{\mathrm{fl} / \mathrm{f}} \mathrm{N}=3\right.$, Foxm $\left.1 \mathrm{cko} N=3, p=0.0335\right)$. The data are presented as the mean \pm SEM. Scale bar, $50 \mu \mathrm{m}$.

FoxP2) in $\mathrm{P} 8$ brains revealed similar decreases in the numbers of neurons in each layer (Fig. $7 D-K$ ). Furthermore, neurons generated at E12.5 (Fig. $7 \mathrm{~L}, \mathrm{M}$ ) and E15.5 (Fig. $7 \mathrm{~N}, \mathrm{O}$ ) were labeled by BrdU injection and observed at P8. As expected, we found a $22.6 \%$ decrease in the number of E15.5-labeled $\mathrm{BrdU}^{+}$cells in the Foxm 1 cko mice (Fig. 7P). We then tested cell death at E14.5 and $\mathrm{P} 8$ by immunostaining of cleaved-caspase 3 and found no significant difference between the controls and Foxm1 mutants, which excluded the possibility that the decrease in $\mathrm{NeuN}^{+}$neurons resulted from cell death (data not shown). We next asked whether the disruption of Foxm1 had behavioral consequences. We tested adult mice for open field activity for over 15 min. Foxm1 mutants were more active than the control mice, as measured by total movement and velocity (Fig. $8 A, B$ ). The traces of the open field trajectory for each genotype showed that mutants were more likely than controls to enter the center zone (Fig. 8I). Furthermore, Foxm1 mutants tended to spend more time in the center than the controls, although this difference was not statistically significant (Fig. 8C). Because anxiety plays an important role in thigmotaxis, which drives mice to move along the wall in the openfield test, and the behavior within the first $5 \mathrm{~min}$ of the test best reflects anxiety levels, we measured the duration in the center zone during the first $5 \mathrm{~min}$. Foxm $1 \mathrm{mu}$ tants spent $59.0 \%$ more time in the center zone compared with the controls (Fig. $8 D, E)$. Identical results were observed for the distance to the center zone, which reflects movement away from the center zone (Fig. $8 F-H$ ). This result raised the possibility that Foxm1 mutants have defects in anxiety behavior. The elevated $\mathrm{O}$-maze test was performed to further elucidate the role of Foxm 1 in anxiety-related behavior. Significant differences in anxiety levels were detected between the mutant and control mice; the frequency of entering and time spent in the open arms was significantly greater for the mutants than for the controls (Fig. $8 \mathrm{~J}, K$ ), supporting the hypothesis that Foxm 1 mutants are less anxious. Because Foxm1 was also ablated in the hippocampus in our Foxm $1^{\mathrm{fl} /}$ fl; Emx1-Cre model, we examined the morphogenesis of the hippocampus and found no differences between the controls and the Foxm 1 mutants (data not shown). We also tested hippocampus-related contextual and cued fear conditioning behaviors. Foxm 1 mutants performed similarly to the controls (Fig. $8 L, M$ ). Thus, the loss of Foxm 1 has no effects on fear memory but leads to reduced anxiety-related behavior.

\section{Discussion}

In the present study, we describe new roles for Foxm1 in controlling INM and cellcycle progression. The inactivation of Foxm1 leads to impaired INM due to a prolonged cell cycle. Impaired INM disturbs AP synchronization and further enhances the transition from APs to BPs. Our study demonstrates that Foxm1 is important for maintaining the balance between self-renewal and differentiation by controlling INM and revealed a link between INM and the cell-cycle regulator Foxm1. More importantly, Foxm1 ablation resulted in reduced anxiety-related behavior.

It has been demonstrated that the cell cycle is required for INM (Huttner and Kosodo, 2005; Schenk et al., 2009; Kosodo et 
A

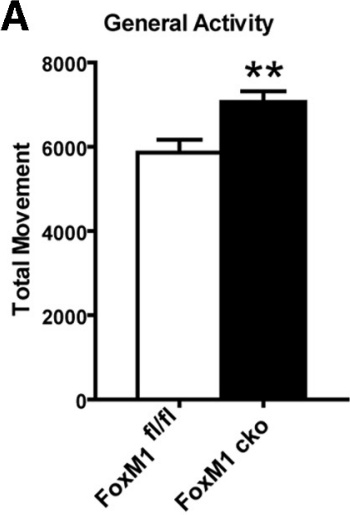

F Distance to zone (total)

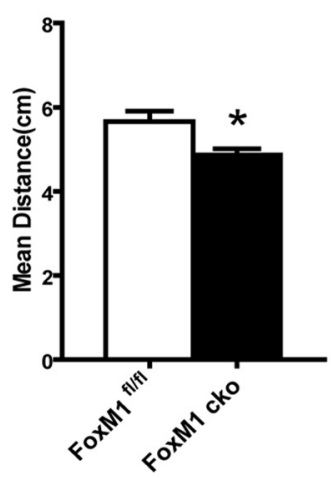

$\mathbf{J}$

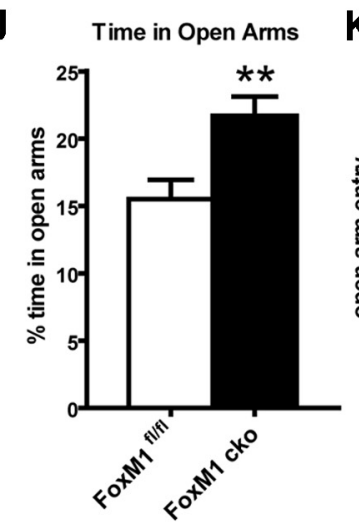

B

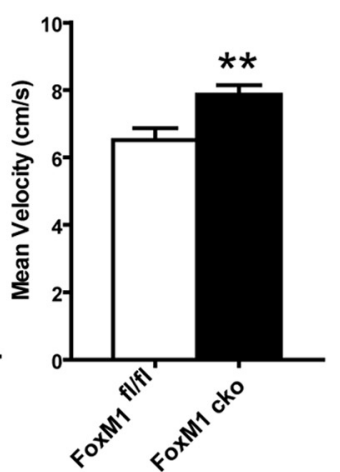

G Distance to zone (5 $\mathrm{min})$
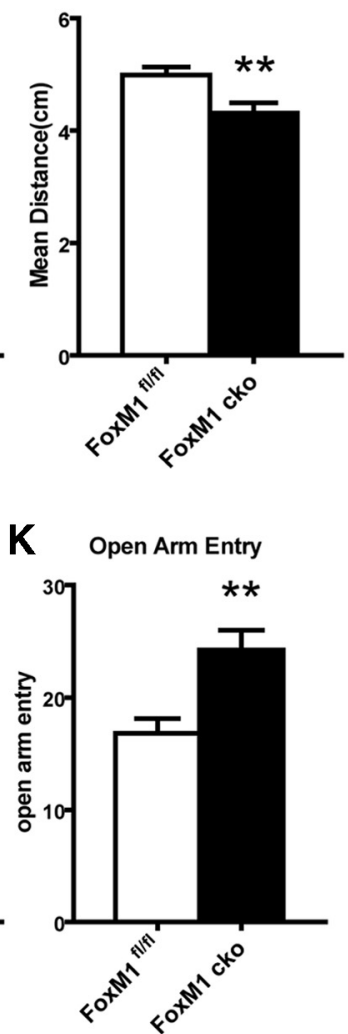

C Duration in zone(total)

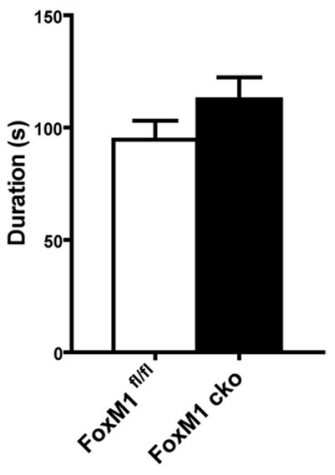

H Distance to zone (10 $\mathrm{min})$

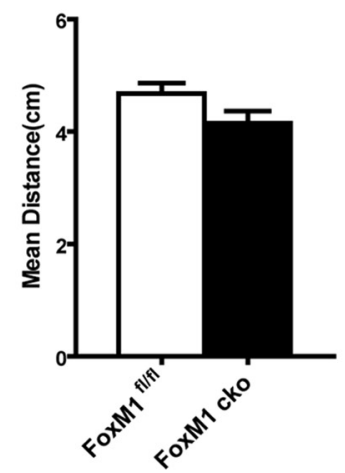

D Juration in zone (5 $\mathrm{min})$

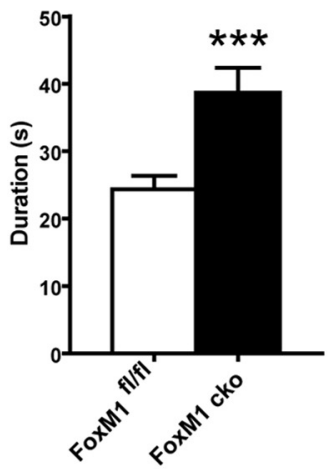

I
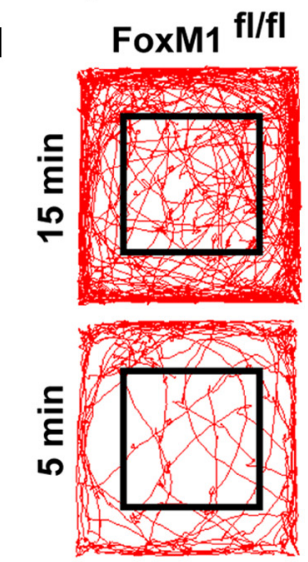

E Duration in zone $(10 \mathrm{~min})$
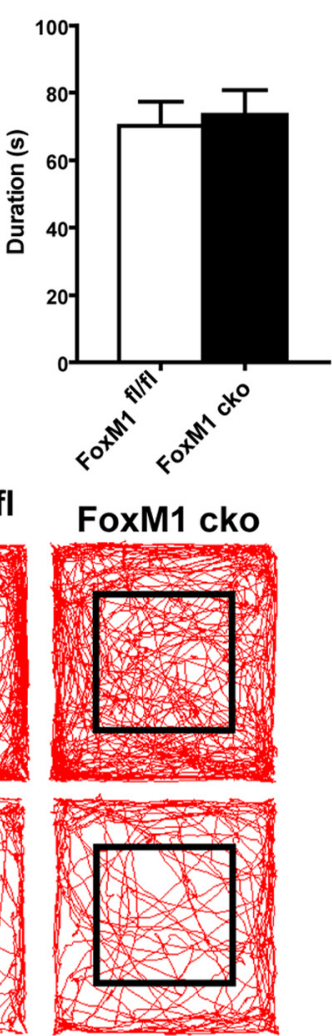
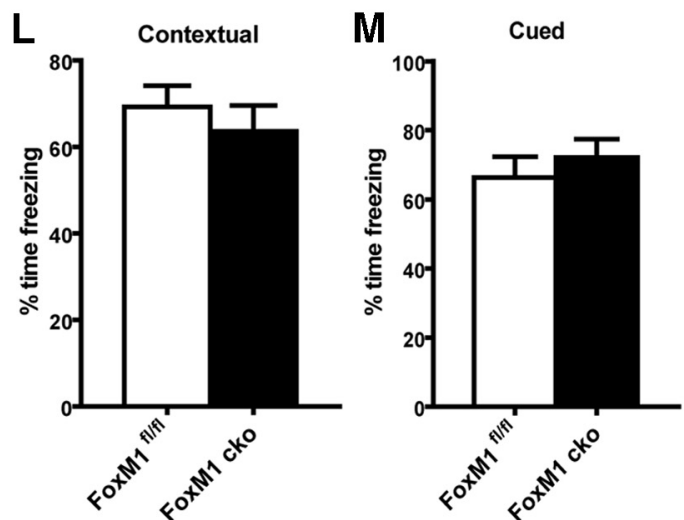

Figure 8. Foxm 1 cko mice display relatively high activity levels and decreased anxiety-related behavior. $A, B$, The general activity levels of the Foxm 1 cko mice were higher than those of the wild-type mice. The total movement was $5858 \pm 308.5 \mathrm{~cm}$ and $7062 \pm 256.5 \mathrm{~cm}$ for the wild-type and Foxm $1 \mathrm{cko}$ mice, respectively $(p=0.0077)$, and the average velocity was $6.5 \pm 0.3 \mathrm{~cm} / \mathrm{s}$ and $7.9 \pm 0.3 \mathrm{~cm} / \mathrm{s}$, respectively $(p=0.0078)$. $C-E$, The Foxm 1 cko mice showed a $59 \%$ increase in the duration spent in the center zone within the first 5 min of an open-field test by straight comparison of the (time spent by the Foxm 1 mutants in the center zone)/(time spent by the control in the center zone) $(p=0.009) . \boldsymbol{F}-\boldsymbol{H}$, The Foxm 1 cko mice traveled a shorter distance to the center zone within the first $5 \mathrm{~min}(p=0.0042)$ and $15 \mathrm{~min}(p=0.0152)$ of an open-field test. $I$, The trajectories of the Foxm ${ }^{\mathrm{fl} / \mathrm{fl}}$ and Foxm 1 cko mice over 5 min and 15 min. Solid line outlines indicate the center zone. $\boldsymbol{J}, \boldsymbol{K}$, In the elevated 0 -maze test, the Foxm 1 cko mice spent significantly more time in the open arms than the wild-type mice $(p=0.0057)$ and made more entries into the open arms $(p=0.0018) . L, M$, There were no significant differences in the freezing time in either the contextual or cued conditioning tests. For the behavior tests, 19 Foxm $l^{\mathrm{fl} / \mathrm{fl}} \mathrm{mice}(10 \mathrm{males}, 9 \mathrm{females})$ and 14 Foxm 1 cko mice ( 7 males, 7 females) were tested. The data are presented as the mean \pm SEM. Scale bar, $50 \mu \mathrm{m}$.

al., 2011; Reiner et al., 2012). The nuclei of progenitors arrested in $S$ phase are distributed basally in the VZ rather than moving toward the apical side, whereas nuclei arrested in $G_{2} / M$ phase stop migrating toward the basal side and accumulate apically (Murciano et al., 2002; Del Bene, 2011). The inhibition of $\mathrm{G}_{1}$ phase results in a basal accumulation of APs (Ueno et al., 2006). Interestingly, the converse is not true; INM is not required for cell-cycle progression. Myosin II disruption prevents apical-tobasal migration in $G_{1}$ phase but has no effects on cell cycle length. In our present study, the disruption of the cell cycle regulator
Foxm1 in the dorsal telencephalon delayed INM. Further analysis of cell-cycle parameters by BrdU/Ki67 and BrdU/IdU double labeling and cumulative BrdU labeling demonstrated that both $\mathrm{S}$ phase and the entire cell cycle were longer in the Foxm1 mutants. Moreover, 1.5/2 h, 1/5 h BrdU/IdU, and BrdU/PH3 double labeling suggested that $\mathrm{G}_{2}$ phase may also be extended in the Foxm 1 mutants. Our study has established a link between INM and the cell cycle regulator Foxm1.

Foxm1 is upregulated at the onset of tumorigenesis (Raychaudhuri and Park, 2011; Koo et al., 2012), consistent with its role in 
controlling cell cycle progression, including mitotic entry, spindle formation, centrosome replication and the $\mathrm{G}_{2} / \mathrm{M}$ checkpoint (Laoukili et al., 2007). By controlling the expression of CDKs at the checkpoints (Kalin et al., 2011), Foxm 1 regulates the $G_{1} / S$ and $\mathrm{G}_{2} / \mathrm{M}$ transitions. The loss of Foxm1 leads to defects in spindle segregation and, consequently, polyploidy in hepatocytes and myocardial cells (Krupczak-Hollis et al., 2004; Ramakrishna et al., 2007). However, polyploidy was not observed in neuronal progenitors in the developing telencephalon of the Foxm $1 \mathrm{mu}-$ tants. Interestingly, we found that the mRNA levels of Cyclin $b 1$ and $C d c 25 b$, downstream targets of Foxm1, were dramatically decreased in the Foxm 1 mutants. In situ hybridization revealed an apical half-specific decrease in $C y c l i n B 1$ and $C d c 25 b$, which suggest that the proper expression of the $C y c l i n b 1$ and $C d c 25 b$ complex may be important for INM.

A key aspect of mammalian cortical neurogenesis is cell fate determination, accompanied by the balance between selfrenewal and differentiation (Bertrand et al., 2002; Miyata et al., 2004; Calegari et al., 2005; Dehay and Kennedy, 2007). INM functions to synchronize APs and to organize APs into groups, ensuring that lateral inhibition occurs in the apical region of the VZ (Ueno et al., 2006; Kageyama et al., 2009; Taverna and Huttner, 2010). In the present study, we observed increased numbers of $\mathrm{Tbr}^{+} \mathrm{BrdU}^{+}$progenitors in the VZ, which suggested that defects in INM and the cell cycle promote the transition from APs to BPs in the VZ and enhance neurogenesis. Furthermore, the deletion of Foxm1 not only impairs INM but also disturbs AP synchronization. APs expressing neurogenic genes are dispersed, which may cause lateral inhibition throughout the whole VZ and result in increased neurogenesis (Götz and Huttner, 2005; Molnár et al., 2011). However, we did not detect any change in the expression of the proneural gene Ngn2. These data indicate that the abnormal transition from APs to BPs in Foxm1 mutants was not caused by changes in Ngn2 or Notch/Delta signaling. Interestingly, the increased number of Tbr $2^{+} \mathrm{PH} 3{ }^{+}$cells in the SVZ may reflect that the BPs in the SVZ also exhibited a slower cellcycle progression, similar to the Foxm1 deficient APs. Further studies are required to reveal the precise underlying mechanism. Together, our data suggest that Foxm 1 is required to maintain the balance of AP self-renewal and differentiation. Disrupting Foxm 1 disturbs INM and the synchronization of APs and promotes the transition from APs to BPs.

The Foxm1 mutants exhibited a slightly decreased number of mature neurons, and more interestingly, a relatively high level of activity, as well as reduced anxiety-related behaviors. Although Foxm1 mutants exhibit no severe cortical abnormalities, it remains unknown whether synapse number, electrophysiological characteristics, or subtle features, such as axon or dendrite positioning, are affected. The prefrontal and cingulate cortices and the amygdala play important roles in processing anxietyrelated behavior (Hall et al., 2001; Viosca et al., 2009), and these three regions contain excitatory neurons originating from Emx1-positive progenitors, in which Foxm1 is normally expressed. It is possible that subtle structures in these regions are altered. Together, our data reveal a new role for Foxm 1 in anxiety-related behavior. Further studies are needed to reveal the detailed mechanism.

\section{References}

Bertrand N, Castro DS, Guillemot F (2002) Proneural genes and the specification of neural cell types. Nat Rev Neurosci 3:517-530. CrossRef Medline

Buchman JJ, Tsai LH (2008) Putting a notch in our understanding of nuclear migration. Cell 134:912-914. CrossRef Medline
Calegari F, Haubensak W, Haffner C, Huttner WB (2005) Selective lengthening of the cell cycle in the neurogenic subpopulation of neural progenitor cells during mouse brain development. J Neurosci 25:6533-6538. CrossRef Medline

Costa RH (2005) FoxM1 dances with mitosis. Nat Cell Biol 7:108-110. CrossRef Medline

Dehay C, Kennedy H (2007) Cell-cycle control and cortical development. Nat Rev Neurosci 8:438-450. CrossRef Medline

Del Bene F (2011) Interkinetic nuclear migration: cell cycle on the move. EMBO J 30:1676-1677. CrossRef Medline

Del Bene F, Wehman AM, Link BA, Baier H (2008) Regulation of neurogenesis by interkinetic nuclear migration through an apical-basal notch gradient. Cell 134:1055-1065. CrossRef Medline

Fietz SA, Huttner WB (2011) Cortical progenitor expansion, self-renewal and neurogenesis-a polarized perspective. Curr Opin Neurobiol 21:2335. CrossRef Medline

Fu Z, Malureanu L, Huang J, Wang W, Li H, van Deursen JM, Tindall DJ, Chen J (2008) Plk1-dependent phosphorylation of FoxM1 regulates a transcriptional programme required for mitotic progression. Nat Cell Biol 10:1076-1082. CrossRef Medline

Gorski JA, Talley T, Qiu M, Puelles L, Rubenstein JL, Jones KR (2002) Cortical excitatory neurons and glia, but not GABAergic neurons, are produced in the Emx1-expressing lineage. J Neurosci 22:6309-6314. Medline

Götz M, Huttner WB (2005) The cell biology of neurogenesis. Nat Rev Mol Cell Biol 6:777-788. CrossRef Medline

Hall J, Thomas KL, Everitt BJ (2001) Cellular imaging of zif268 expression in the hippocampus and amygdala during contextual and cued fear memory retrieval: selective activation of hippocampal CA1 neurons during the recall of contextual memories. J Neurosci 21:2186-2193. Medline

Huttner WB, Kosodo Y (2005) Symmetric versus asymmetric cell division during neurogenesis in the developing vertebrate central nervous system. Curr Opin Cell Biol 17:648-657. CrossRef Medline

Kageyama R, Ohtsuka T, Shimojo H, Imayoshi I (2009) Dynamic regulation of Notch signaling in neural progenitor cells. Curr Opin Cell Biol 21:733740. CrossRef Medline

Kalin TV, Ustiyan V, Kalinichenko VV (2011) Multiple faces of FoxM1 transcription factor: lessons from transgenic mouse models. Cell Cycle 10:396-405. CrossRef Medline

Kalinichenko VV, Zhou Y, Bhattacharyya D, Kim W, Shin B, Bambal K, Costa RH (2002) Haploinsufficiency of the mouse forkhead box f1 gene causes defects in gall bladder development. J Biol Chem 277:12369-12374. CrossRef Medline

Koo CY, Muir KW, Lam EW (2012) FOXM1: from cancer initiation to progression and treatment. Biochim Biophys Acta 1819:28-37. CrossRef Medline

Kosodo Y (2012) Interkinetic nuclear migration: beyond a hallmark of neurogenesis. Cell Mol Life Sci 69:2727-2738. CrossRef Medline

Kosodo Y, Suetsugu T, Suda M, Mimori-Kiyosue Y, Toida K, Baba SA, Kimura A, Matsuzaki F (2011) Regulation of interkinetic nuclear migration by cell cycle-coupled active and passive mechanisms in the developing brain. EMBO J 30:1690-1704. CrossRef Medline

Krupczak-Hollis K, Wang X, Kalinichenko VV, Gusarova GA, Wang IC, Dennewitz MB, Yoder HM, Kiyokawa H, Kaestner KH, Costa RH (2004) The mouse forkhead box $\mathrm{m} 1$ transcription factor is essential for hepatoblast mitosis and development of intrahepatic bile ducts and vessels during liver morphogenesis. Dev Biol 276:74-88. CrossRef Medline

Laoukili J, Stahl M, Medema RH (2007) FoxM1: at the crossroads of ageing and cancer. Biochim Biophys Acta 1775:92-102. CrossRef Medline

Laoukili J, Alvarez M, Meijer LA, Stahl M, Mohammed S, Kleij L, Heck AJ, Medema RH (2008) Activation of FoxM1 during $G_{2}$ requires cyclin A/Cdk-dependent relief of autorepression by the FoxM1 N-terminal domain. Mol Cell Biol 28:3076-3087. CrossRef Medline

Latasa MJ, Cisneros E, Frade JM (2009) Cell cycle control of Notch signaling and the functional regionalization of the neuroepithelium during vertebrate neurogenesis. Int J Dev Biol 53:895-908. CrossRef Medline

Martynoga B, Morrison H, Price DJ, Mason JO (2005) Foxg1 is required for specification of ventral telencephalon and region-specific regulation of dorsal telencephalic precursor proliferation and apoptosis. Dev Biol 283: 113-127. CrossRef Medline

Miyata T, Kawaguchi A, Saito K, Kawano M, Muto T, Ogawa M (2004) 
Asymmetric production of surface-dividing and non-surface-dividing cortical progenitor cells. Development 131:3133-3145. CrossRef Medline

Molnár Z, Vasistha NA, Garcia-Moreno F (2011) Hanging by the tail: progenitor populations proliferate. Nat Neurosci 14:538-540. CrossRef Medline

Murciano A, Zamora J, López-Sánchez J, Frade JM (2002) Interkinetic nuclear movement may provide spatial clues to the regulation of neurogenesis. Mol Cell Neurosci 21:285-300. CrossRef Medline

Nowakowski RS, Lewin SB, Miller MW (1989) Bromodeoxyuridine immunohistochemical determination of the lengths of the cell cycle and the DNA-synthetic phase for an anatomically defined population. J Neurocytol 18:311-318. CrossRef Medline

Radhakrishnan SK, Gartel AL (2008) FOXM1: the Achilles' heel of cancer? Nat Rev Cancer 8:c1; author reply c2. CrossRef Medline

Ramakrishna S, Kim IM, Petrovic V, Malin D, Wang IC, Kalin TV, Meliton L, Zhao YY, Ackerson T, Qin Y, Malik AB, Costa RH, Kalinichenko VV (2007) Myocardium defects and ventricular hypoplasia in mice homozygous null for the forkhead box M1 transcription factor. Dev Dyn 236: 1000-1013. CrossRef Medline

Raychaudhuri P, Park HJ (2011) FoxM1: a master regulator of tumor metastasis. Cancer Res 71:4329-4333. CrossRef Medline

Reiner O, Sapir T, Gerlitz G (2012) Interkinetic nuclear movement in the ventricular zone of the cortex. J Mol Neurosci 46:516-526. CrossRef Medline

Schenk J, Wilsch-Bräuninger M, Calegari F, Huttner WB (2009) Myosin II is required for interkinetic nuclear migration of neural progenitors. Proc Natl Acad Sci U S A 106:16487-16492. CrossRef Medline

Schüller U, Zhao Q, Godinho SA, Heine VM, Medema RH, Pellman D, Rowitch DH (2007) Forkhead transcription factor FoxM1 regulates mitotic entry and prevents spindle defects in cerebellar granule neuron precursors. Mol Cell Biol 27:8259-8270. CrossRef Medline

Shitamukai A, Matsuzaki F (2012) Control of asymmetric cell division of mammalian neural progenitors. Dev Growth Differ 54:277-286. CrossRef Medline

Taverna E, Huttner WB (2010) Neural progenitor nuclei IN motion. Neuron 67:906-914. CrossRef Medline

Tian C, Gong Y, Yang Y, Shen W, Wang K, Liu J, Xu B, Zhao J, Zhao C (2012)
Foxg1 has an essential role in postnatal development of the dentate gyrus. J Neurosci 32:2931-2949. CrossRef Medline

Ueno M, Katayama K, Yamauchi H, Nakayama H, Doi K (2006) Cell cycle progression is required for nuclear migration of neural progenitor cells. Brain Res 1088:57-67. CrossRef Medline

Viosca J, Lopez de Armentia M, Jancic D, Barco A (2009) Enhanced CREBdependent gene expression increases the excitability of neurons in the basal amygdala and primes the consolidation of contextual and cued fear memory. Learn Mem 16:193-197. CrossRef Medline

Wang X, Kiyokawa H, Dennewitz MB, Costa RH (2002) The forkhead box $\mathrm{m} 1 \mathrm{~b}$ transcription factor is essential for hepatocyte DNA replication and mitosis during mouse liver regeneration. Proc Natl Acad Sci U S A 99: 16881-16886. CrossRef Medline

Wang Z, Park HJ, Carr JR, Chen YJ, Zheng Y, Li J, Tyner AL, Costa RH, Bagchi S, Raychaudhuri P (2011) FoxM1 in tumorigenicity of the neuroblastoma cells and renewal of the neural progenitors. Cancer Res 71:42924302. CrossRef Medline

Wierstra I, Alves J (2007) FOXM1, a typical proliferation-associated transcription factor. Biol Chem 388:1257-1274. CrossRef Medline

Willardsen MI, Link BA (2011) Cell biological regulation of division fate in vertebrate neuroepithelial cells. Dev Dyn 240:1865-1879. CrossRef Medline

Xue L, Chiang L, He B, Zhao YY, Winoto A (2010) FoxM1, a forkhead transcription factor is a master cell cycle regulator for mouse mature $\mathrm{T}$ cells but not double-positive thymocytes. PLoS ONE 5:e9229. CrossRef Medline

Yokomine K, Senju S, Nakatsura T, Irie A, Hayashida Y, Ikuta Y, Harao M, Imai K, Baba H, Iwase H, Nomori H, Takahashi K, Daigo Y, Tsunoda T, Nakamura Y, Sasaki Y, Nishimura Y (2010) The forkhead box M1 transcription factor as a candidate of target for anti-cancer immunotherapy. Int J Cancer 126:2153-2163. CrossRef Medline

Zhang N, Wei P, Gong A, Chiu WT, Lee HT, Colman H, Huang H, Xue J, Liu M, Wang Y, Sawaya R, Xie K, Yung WK, Medema RH, He X, Huang S (2011) FoxM1 promotes beta-catenin nuclear localization and controls Wnt target-gene expression and glioma tumorigenesis. Cancer Cell 20: 427-442. CrossRef Medline

Zhong W, Chia W (2008) Neurogenesis and asymmetric cell division. Curr Opin Neurobiol 18:4-11. CrossRef Medline 